Illinois State University

ISU ReD: Research and eData

Theses and Dissertations

$10-7-2014$

\title{
Genetic Analysis of TON2 Dependent Processes in Microtubule Organization in Arabidopsis thaliana
}

Samantha Nicole Atkinson

Illinois State University, samanthanatkinson@gmail.com

Follow this and additional works at: https://ir.library.illinoisstate.edu/etd

Part of the Cell Biology Commons, and the Genetics Commons

\section{Recommended Citation}

Atkinson, Samantha Nicole, "Genetic Analysis of TON2 Dependent Processes in Microtubule Organization in Arabidopsis thaliana" (2014). Theses and Dissertations. 265.

https://ir.library.illinoisstate.edu/etd/265

This Thesis is brought to you for free and open access by ISU ReD: Research and eData. It has been accepted for inclusion in Theses and Dissertations by an authorized administrator of ISU ReD: Research and eData. For more information, please contact ISUReD@ilstu.edu. 


\title{
GENETIC ANALYSIS OF TON2 DEPENDENT PROCESSES IN MICROTUBULE ORGANIZATION IN ARABIDOPSIS THALIANA
}

\author{
Samantha N. Atkinson
}

51 Pages

December 2014

Microtubules carry out many functions within the cell. They're used during mitosis and meiosis to move chromosomes to opposite sides of the cell so that cell division can occur. They're also used as structural support for the cell and are involved in establishing the cell shape. Microtubules are also able to reorient from a longitudinal orientation to a transverse orientation in response to gibberellic acid and auxin (two hormones that are involved in cell elongation). The mechanism for how this reorientation occurs is unknown. The TONNEAU2 (TON2) protein is necessary for proper microtubule organization. We looked at how TON2 affects microtubule orientation and nucleation in response to the hormones gibberellic acid and auxin and found that while the ton 2 mutant can reorient in response to the hormones it is less efficient. We also found that nucleation mode is not causing the reorientation. Previously it was found that TON2 interacts with the POK protein. POK is a protein that interacts with the phragmoplast and helps orient it for proper formation of the cell plate. We looked at POK localization and timing in ton2 mutants, which lack a PPB. POK's presence overlapped with the cell cycle stages that TON2 is present during and localized to the same place the PPB used to inhabit. RIC1 is another putative TON2 interacting protein. 
We tested the genetic relationship between RIC1 and TON2 in cell shape determination. Our data shows that TON2 could be epistatic to RIC1 by comparing the neck and lobe lengths of pavement cells in wild type, ric $_{1-1}$ mutants, ton 2 mutants, and $r i_{1-1}$ ton 2

double mutants, but more data is needed to confirm this hypothesis. The double mutant had the same phenotype of no or few and small lobes as the ton 2 mutant. 
GENETIC ANALYSIS OF TON2 DEPENDENT PROCESSES IN MICROTUBULE

ORGANIZATION IN ARABIDOPSIS

SAMANTHA N. ATKINSON

A Thesis Submitted in Partial Fulfillment of the Requirements for the Degree of

MASTER OF SCIENCE

School of Biological Sciences

ILLINOIS STATE UNIVERSITY 
(C) 2014 Samantha N. Atkinson 
GENETIC ANALYSIS OF TON2 DEPENDENT PROCESSES IN MICROUTBULE ORGANIZATION IN ARABIDOPSIS THALIANA

SAMANTHA N. ATKINSON

COMMITTEE MEMBERS:

Viktor Kirik, Chair

Thomas Hammond

John Sedbrook 


\section{ACKNOWLEDGMENTS}

I would like to thank my advisor Dr. Viktor Kirik for his support, advice, and for sharing his knowledge throughout my Master's program. I would also like to thank my committee members, Drs. Viktor Kirik, Thomas Hammond, and John Sedbrook for sharing their time and experience with me.

I would also like to thank the School of Biological Sciences for supporting my work here with a graduate assistantship. Also, the Beta Lambda chapter of Phi Sigma Biological Science Honors Society for their funding through a Weigel Grant and social events, making a very welcome environment while transitioning into graduate student life.

In addition I would like to thank my friends and family for their support, understanding, and their never ending belief in me. Special thanks go out to my aunt, Dr. Lynn A. Tovar, for her support and help when times got a little rough.

I dedicate this thesis to my parents, Scott and JuLee Atkinson, and my late grandfather, James E. Atkinson. They have all believed in and supported me my entire life and I would not have accomplished all that I have without them. Thanks Mom and Dad for your never-ending support and belief that I can do anything if I just put my mind to it! 


\section{CONTENTS}

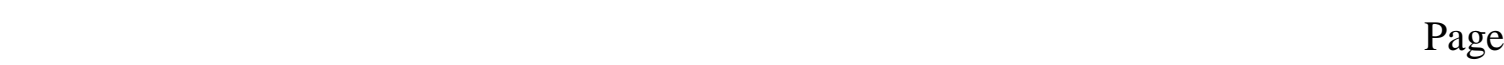

ACKNOWLEDGMENTS $\quad$ i

CONTENTS

TABLES $\quad$ iv

FIGURES $\quad$ V

CHAPTER

I. MICROTUBULE REORIENTATION 1

Introduction 1

$\begin{array}{lr}\text { Results } & 7\end{array}$

Discussion 13

$\begin{array}{ll}\text { II. POK/TON2 INTERACTIONS } & 18\end{array}$

$\begin{array}{ll}\text { Introduction } & 18\end{array}$

Results 20

$\begin{array}{ll}\text { Discussion } & 29\end{array}$

III. RIC1 EFFECT ON CELL SHAPE 31

Introduction $\quad 31$

Results $\quad 35$

Discussion $\quad 40$

IV. METHODS 42

Plant Growth Conditions $\quad 42$

Plant Transformation $\quad 42$

Microscopy 43 
Impressions of Epidermis

Image J

44

DNA Isolation

45

PCR Primers and Conditions

REFERENCES 


\section{TABLES}

Table $\quad$ Page

1. Genetic crosses done with ton2 and pok mutants 26

2. DNA isolation buffers 46

3. PCR primers 47 


\section{FIGURES}

Figure $\quad$ Page

1. Examples of branching, parallel, and de novo nucleation 3

2. Proportions of branching, parallel, or de novo nucleation in hormone-treated cells

3. Frequency of different nucleation types during 90 minutes of hormone-induced microtubule reorientation

4. Ratios of nucleation modes measured in experiments with reduced laser light exposure time

5. Nucleation efficiency and branching nucleation angles in hormone-treated cells

6. $\mathrm{POK}_{\mathrm{CT}}$ signal in wild type plants with a Cyclin B1-GFP marker at 0,10 , and 20 minutes to show cell cycle of timing of POK localization

7. POK localization using YFP: TUA5

8. Gel verification of POK localization

9. Weak ton $2 \times$ strong pok

10. Weak pok x weak ton2

11. PM-TON2 and RIC1 overexpression comparison

12. Comparison of pavement cells in different cell lines

13. Schematic of wild type cell impression

14. Average lobe and neck length per cell line 


\section{CHAPTER I \\ MICROTUBULE REORIENTATION}

\section{Introduction}

Microtubules are long hollow tubes made from alpha/beta tubulin subunits that are assembled in a head to tail orientation. Cells arrange microtubule polymers into different types of co-aligned arrays. Microtubule orientation is instrumental in chromosome separation, cell division, cell morphogenesis, and for directionality of trafficking processes in polarized cells (Paradez et al., 2006; Chan et al., 2011). In plant cells during interphase, cortical microtubules will determine the direction of cell expansion by guiding deposition of cell wall components (Paradez et al., 2006; Gutierrez et al., 2009). Cortical microtubules are the microtubules found in the cortex, the specialized layer of cytoplasm directly below the plasma membrane that functions as mechanical support for the plasma membrane (PM). Intracellular structures, called microtubule organizing centers (MTOCs), regulate microtubule organization into arrays (Pickett-Heaps, 1969). Plants do not have centrosomes (a type of MTOC) so they must rely on noncentrosomal microtubule arrays for various cellular functions, like the establishment of cellular polarity and intracellular transport (reviewed in Bartolini and Gundersen, 2006).

To initiate new cortical microtubules plants use nucleation complexes. Nucleation complexes are made of 3 main components: $\gamma$-tubulin, GCP2 \& 3, and GCP4- 
6 (Fishel and Dixit, 2013). $\gamma$-tubulin is essential for the creation and organization of new cortical microtubule arrays and its absence results in severe developmental defects and disease (Fishel and Dixit, 2013). The $\gamma$-tubulin must complex with other proteins to form microtubule nucleation complexes, these proteins being called $\gamma$-tubulin complex proteins (GCPs; Fishel and Dixit, 2013). First a small complex is formed between $\gamma$ tubulin and GCPs two and three and is called a $\gamma$-tubulin small complex ( $\gamma$-TuSC). The $\gamma$-TuSC will then associate with GCPs four through six to form a $\gamma$-tubulin ring complex $(\gamma$-TuRC); which is a powerful nucleator that acts as a template for microtubule assembly (Fishel and Dixit, 2013). The way these $\gamma$-TuRCs dock and the mechanism for microtubule elongation is unknown. There are three modes that nucleation can occur in: branching, parallel, and de novo (Kirik et al., 2012; Fishel and Dixit, 2013; Atkinson et al., 2014). Branching nucleation is microtubule dependent nucleation where the new microtubule initiates at a 40-60 degree angle from the mother microtubule. Parallel occurs when the new microtubule is initiated alongside the mother microtubule. De novo nucleation is microtubule independent nucleation, the new microtubule initiates without the presence of a mother microtubule (Kirik et al., 2012; Fishel and Dixit, 2013; Figure $1)$. 


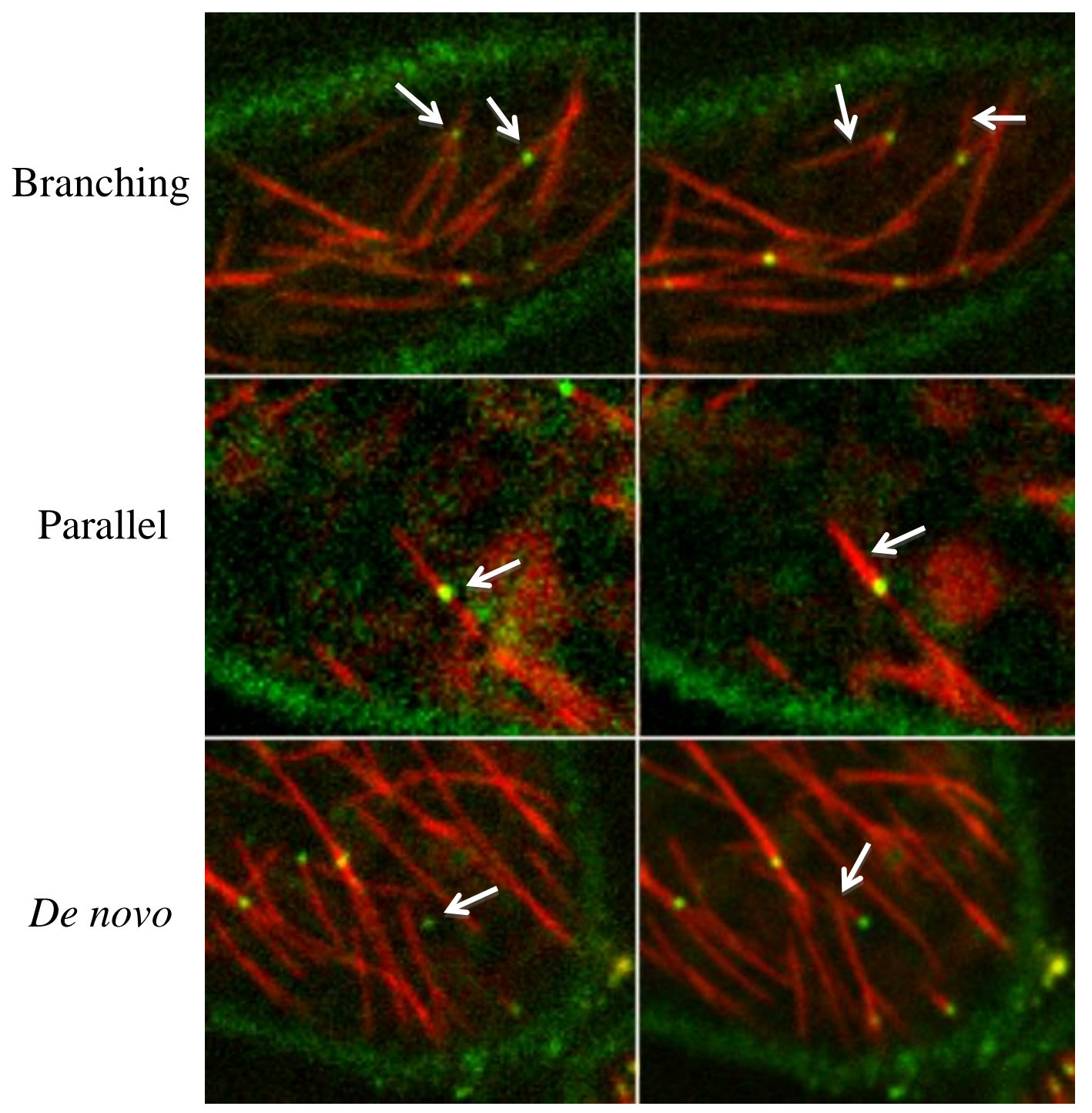

Figure 1. Examples of branching, parallel, and de novo nucleation. Branching occurs at an angle of the mother microtubule, parallel along the mother microtubule, and de novo occurs without a mother microtubule. Arrows in the left panels point to the nucleation complex that is going to nucleate and arrows in the right panels point to the emerging microtubule nucleated by the complex. Green signal is $\mathrm{GCP}_{2}$-GFP nucleation complex marker and the red signal is a mCherry-TUB5 microtubule marker. 
The process of cortical microtubule rearrangement is not well understood. Recent findings show that during microtubule reorientation several mechanisms need to be coordinated, including the formation of new microtubules in the discordant orientation, their amplification, and interactions with other microtubules. Generally, reorientation begins with the appearance of discordant microtubules that effectively contribute to new arrays (Yuan et al., 1995; Sambade et al., 2012; Lindeboom et al., 2013; Vineyard et al., 2013). In the longitudinal to transverse reorientation stimulated by rapid cell elongation, transverse microtubules appear from the midzone of orthogonal sidewalls, forming an isotropic transition array in the star or basket-like configuration at the onset of reorientation (Sambade et al., 2012; Vineyard et al., 2013). As cells enter the rapid elongation phase, more transverse microtubules appear from the longitudinal sidewalls, spreading as a wave towards cell ends (Sambade et al., 2012). The appearance of transverse discordant microtubules was stimulated by cell growth promoting hormones gibberellic acid and auxin, whereas auxin hormone inhibitors suppressed transverse microtubules (Sambade et al., 2012; Vineyard et al., 2013).

Discordant microtubules were shown to amplify selectively through a microtubule severing mechanism (Lindeboom et al., 2013). In the process of light-induced reorientation from transverse to longitudinal arrays, growing ends of seeding longitudinal microtubules encounter preexisting transverse microtubules, and often form crossovers. Microtubule crossovers attract katanin proteins which sever new microtubules preferentially, creating new plus ends that can either start depolymerization or, alternatively, can initiate a new growing end (Wightman and Turner, 2007; Lindeboom et 
al., 2013; Wightman et al., 2013). The new growing ends can initiate more plus ends, leading to a rapid amplification of longitudinally oriented microtubules.

Selective removal of longitudinally oriented microtubules has been suggested to lead to transverse orientation of microtubule arrays (Ehrhardt and Shaw, 2006). A microtubule-associated protein CLASP has been shown to accumulate and suppress catastrophes at the borders between periliclinal and anticlinal cell surfaces (Ambrose et al., 2011). Such localized anticatastrophy activity driven by CLASP localized along the longitudinal sidewalls would promote transverse ordering of microtubules by preferential removal of longitudinal microtubules (Ambrose et al., 2011). Time-lapse analysis of reorganizing microtubule arrays after treatment with a gibberellic acid and auxin hormone mix showed an increase in the frequency of transverse microtubules during array reorientation, suggesting an active mechanism promoting formation of new microtubules in the transverse orientation (Sambade et al., 2012; Vineyard et al., 2013). Furthermore, hormone induction rapidly depleted the number of plus ends on the periclinal surface (Vineyard et al., 2013), and nucleation of new microtubules was decreased during light-induced microtubule reorientation (Lindeboom et al., 2013), suggesting that the mechanism of microtubule array reorientation involves changes in new microtubule initiation.

Environmental factors can influence microtubule orientation, but the mechanisms that drive this reorientation are unknown. There are currently many theories addressing how this mechanism could work, including microtubule motors, treadmilling, nucleation, and differential microtubule dynamics (Vineyard et al., 2013). It has been shown that 
light exposure will suppress cell elongation and induce microtubules to reorient from a transverse array into a longitudinal array, in relation to the long axis of the cell (Kigel and Cosgrove, 1991; Paradez et al., 2006; Kirik et al., 2012; Lindeboom et al., 2013). The hormones gibberellic acid and auxin have been shown to have the opposite effect; they reorient longitudinal microtubules into a transverse array (Vineyard et al., 2013).

Microtubules of the ton 2 mutant failed to reorient in response to light and also had defects in branching nucleation (defined as microtubules that nucleate at an angle to the existing microtubule) but no other type of nucleation (Kirik et al., 2012). This defect in branching nucleation is the aspect of the mutation that allowed for the testing of the role of branching nucleation in microtubule reorientation in response to hormones. The TON2 protein is a B', subunit of the PP2A (protein phosphatase 2A; Camilleri et al., 2002). The ton 2 mutant has deficiencies in the plant's shape: dwarf seedlings and plantlets that are thicker without affecting the plant organ formation (Camilleri et al., 2002). When looking at the cellular level it has been found that the ton 2 mutant has deformities in cell arrangement, shape, and size due to an inability to properly elongate and form division planes (Camilleri et al., 2002; Kirik et al., 2012). The ton2 mutants also have defects in organization of cortical microtubules (Camilleri et al., 2002; Kirik et al., 2012). It has also been found that cortical microtubules in ton 2 mutant cells cannot reorient in response to light (Kirik et al., 2012).

This study aimed to look at whether nucleation mode, specifically branching nucleation, was a possible mechanism for cortical microtubule reorientation in response 
to hormones. It was found that the mode of nucleation and the angle of branching nucleations did not affect the cortical microtubule reorientation.

\section{Results}

Microtubule nucleation modes, efficiency, and branching angles are not changed during hormone-induced microtubule reorientation

Recent data suggested that microtubule branching nucleation may play a role in light-induced reorientation of microtubule arrays from transverse to longitudinal arrays by generating discordant microtubules at the beginning of the reorientation process (Kirik et al., 2012; Cao et al., 2013; Lindeboom et al., 2013). Here we analyzed different microtubule nucleation modes during the hormone-induced microtubule reorientation into transverse arrays.

To visualize microtubule nucleation events during the hormone-induced microtubule reorientation we used plants coexpressing GCP2:GFP (nucleation complex marker) and mCherry:TUB5 (microtubule marker) constructs. Time-lapse images of reorienting microtubule arrays were acquired over 90 minute intervals, in which the majority of wild type cells and approximately one quarter of the ton 2 cells adopted transverse array configuration. We found that the proportion of different microtubule nucleation types, including branching, nucleations parallel to existing microtubules, and de-novo nucleations initiated at the cell cortex areas not occupied by microtubules, did not change significantly in wild type cells treated with hormones (Fishers exact test $\mathrm{p}>0.05$; Figure 2). 


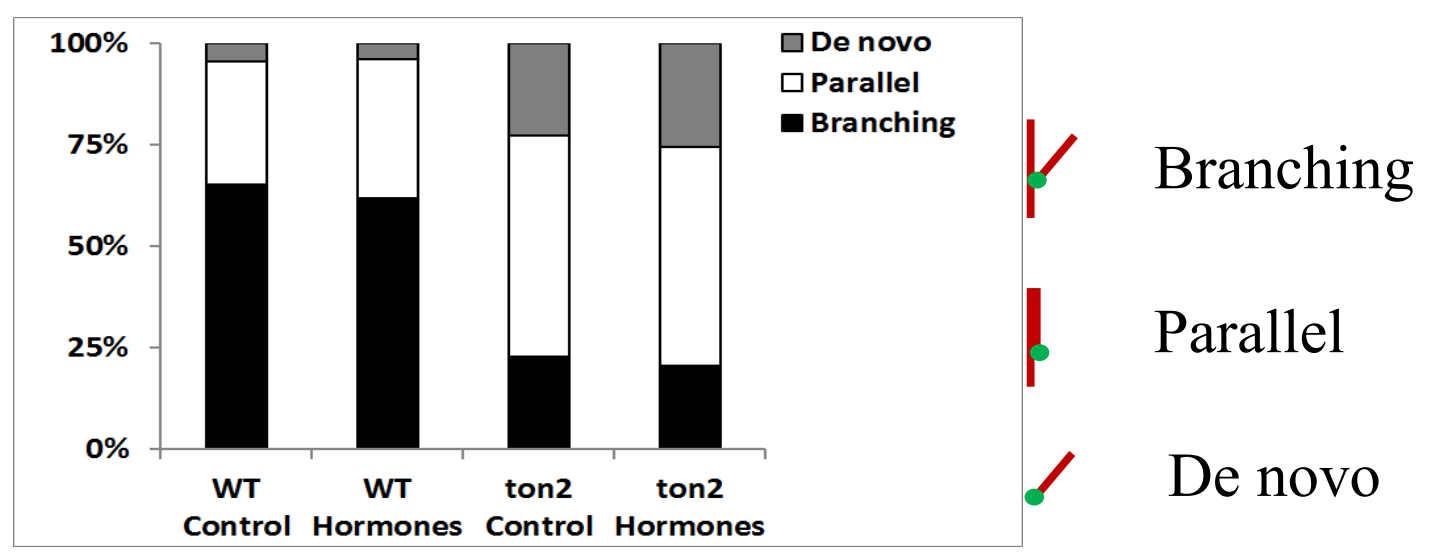

Figure 2. Proportions of branching, parallel, or de novo nucleations in hormonetreated cells. Nucleation data were collected over 90 minutes following the hormone or mock treatment from 4 wild type cells (from 4 different seedlings) and 3 ton 2 cells (from 3 different seedlings) for each treatment. Branching nucleations comprised $65.2 \%$ in solvent-treated wild type, $61.9 \%$ in hormone-treated wild type, $23.0 \%$ in ton 2 solvent-treated, and $20.5 \%$ in ton 2 hormone-treated. Parallel nucleations comprise $30.4 \%$ in solvent-treated wild type, $34.36 \%$ in hormone treated wild type, $54.0 \%$ in ton 2 solvent-treated, and $53.9 \%$ in ton 2 hormonetreated. De novo nucleations comprised $4.4 \%$ in solvent-treated wild type, $3.7 \%$ in hormone-treated wild type, $23.0 \%$ in ton 2 solvent-treated and $25.65 \%$ in ton 2 hormone-treated. 
There was also no effect of hormones on the balance between different nucleation types in the ton 2 mutant. Similar to the reduction of microtubule nucleation frequency during light-induced microtubule reorientation into longitudinal arrays (Lindeboom et al., 2013), the frequency of microtubule nucleation events declined during the hormoneinduced transition to transverse arrays (Figure 3).

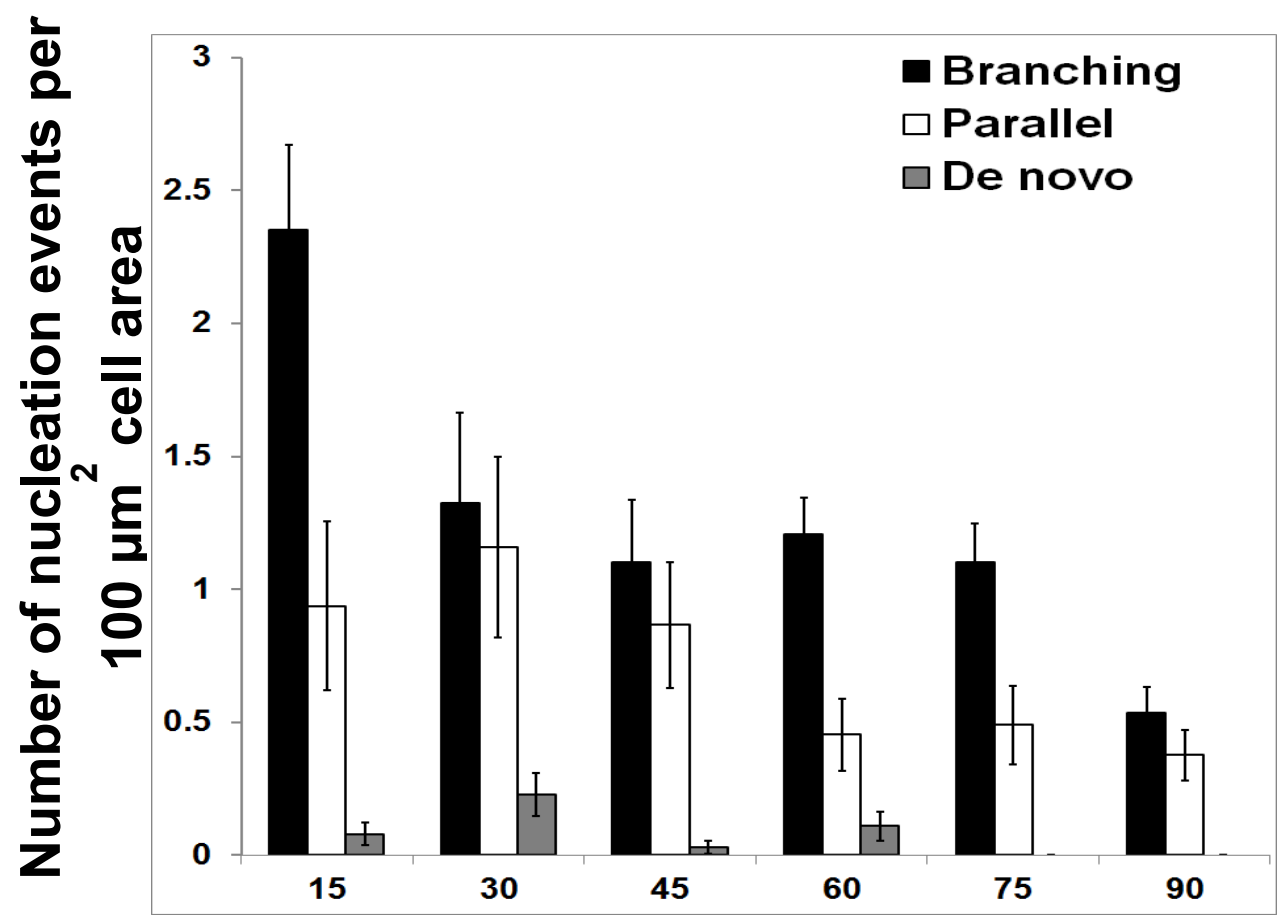

Figure 3. Frequency of different nucleation types during 90 minutes of hormone-induced microtubule reorientation. Data were collected in 15 minute time bins over 90 minutes of hormone treatment. Number of cells $n=4$, error bars show standard error of mean. 
To test if exposure to laser light affected microtubule nucleation, we used imaging conditions with greatly reduced acquisition times. Time-lapse images were acquired in the first 5 minutes followed by another 5 minutes acquisition interval after 1 hour of hormone treatment. We found no change in the ratio of different nucleation modes (Figure 4), suggesting that long time-lapse imaging conditions did not affect microtubule nucleation modes.

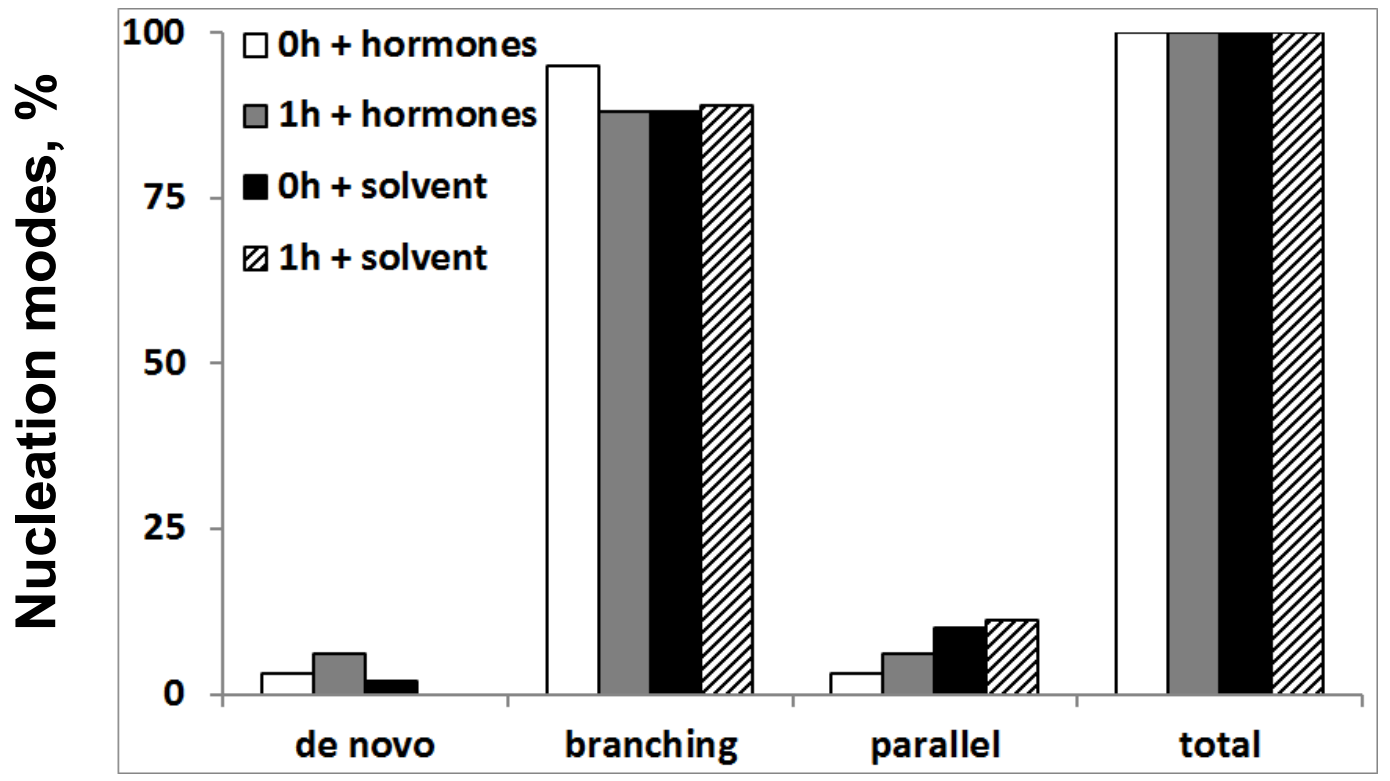

Figure 4. Ratios of nucleation modes measured in experiments with reduced laser light exposure time. Time lapse images were taken in the first 5 minutes followed by another 5 minutes acquisition interval after 1 hour of hormone treatment. 
To test if hormones influenced the probability to initiate formation of new microtubules from recruited gamma-tubulin complexes, we measured the fraction of microtubule initiation events from the GCP2-GFP labeled nucleation complexes stabilized at the cell cortex for at least 6 seconds. Hormones had no significant effect on the nucleation probability in wild type (59.6\% in control, $60 \%$ in hormone treated cells) and in the ton 2 mutant (39.5\% in control, $37.5 \%$ in hormone treated cells; Figure 5A), but the probability to initiate microtubules from stabilized nucleation complexes was significantly reduced in the ton 2 mutant $(\mathrm{p}<0.05$, Fisher's exact test).

In microtubule branching nucleation, the angles of new microtubules vary between 30 and 60 degrees. Since microtubule branching at smaller angles lead to increased coalignment (Nakamura and Hashimoto, 2009) and, conversely, microtubule interactions at larger angles were shown to contribute to microtubule array reorientation (Lindeboom et al., 2013), we tested if there was a change in wild type branching nucleation angles during the hormone-induced microtubule reorientation. We found that microtubule branching angles remained constant (Figure 5B), suggesting that the mechanism of reorientation into transverse array does not include regulation of the microtubule branching nucleation angles. 
A

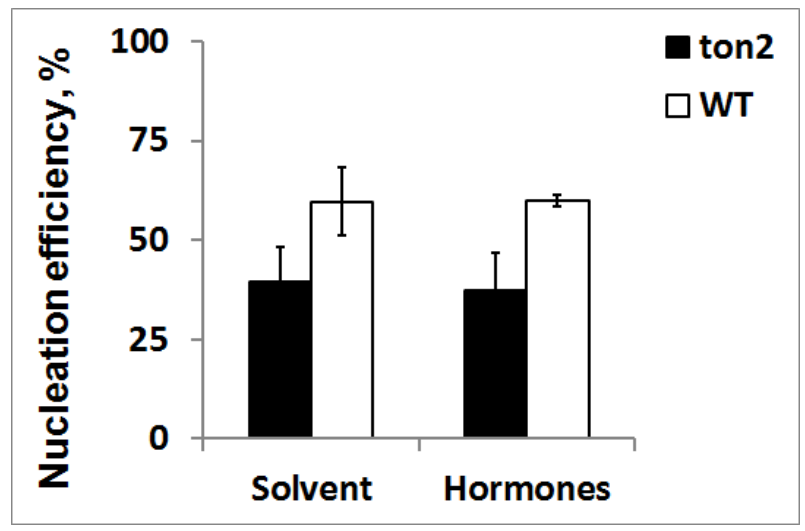

B

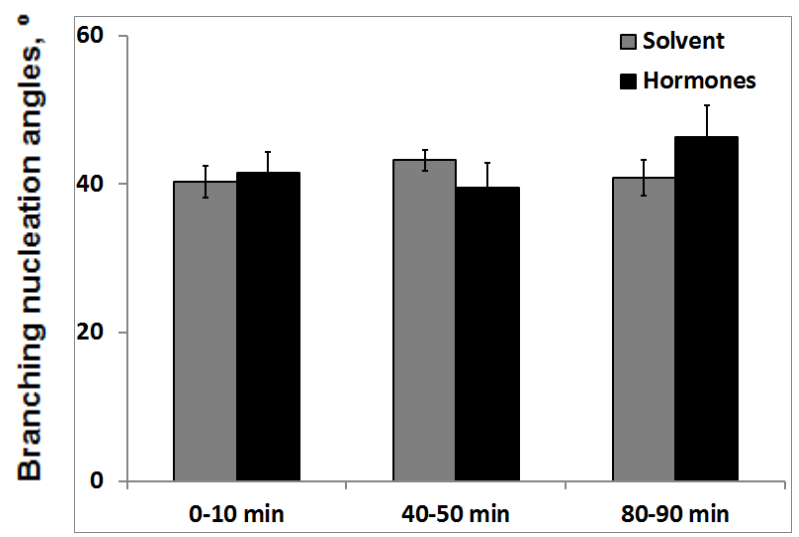

Figure 5. Nucleation efficiency and branching nucleation angles in hormone-treated cells. A) Microtubule nucleation efficiency of the $\gamma$-tubulin complexes recruited to the cell cortex. Nucleation efficiency calculated as the number of total nucleations (branching + parallel + de novo) divided by the sum of the total nucleations and failed nucleation events. Failed nucleation events were scored as GCP2 complexes which did not promote nucleation during at least 6 seconds. $\mathrm{N}=4$ cells per each case. B) Branching nucleation angles. In both cases, without and under hormones treatment, the average branching nucleation angle stayed around 40 degrees. The distribution of branching nucleation angles did not change significantly during the hormone induced microtubule reorientation ( $\mathrm{P}>0.05$, two tailed Student's T-test). For each time window 4 cells were analyzed, error bars show the standard deviation of mean. 
ton2 mutant initiates less transversely oriented MTs from the cell sides.

Experimental data and computer modeling suggested that transverse microtubules originating at the anticlinal cell sides could drive reorientation of the periclinal microtubule arrays (Sambade et al., 2012; Vineyard et al., 2013). The mechanism generating these transverse microtubules is not known, but it has been speculated that microtubule nucleation and/or selective stabilization of microtubules at the anticlinal side walls may be involved (Ambrose et al., 2011; Sambade et al., 2012; Vineyard et al., 2013). Mutants in the TON2 gene show reduced microtubule branching nucleation frequency, reduced microtubule stability (Kirik et al., 2012), and a reduced ability of the gamma-tubulin complexes to initiate microtubules in hypocotyl cells (Figure 5A), providing a possibility to test if these microtubule processes play a role in the formation of transversely oriented microtubules originated at anticlinal cell sides.

\section{Discussion}

In plant cells most microtubules nucleating from gamma-tubulin complexes form branches at an average angle of 40 degrees to existing microtubules. Computer modeling and microtubule organization in mutants with affected branching nucleation angles suggest that branching nucleation promotes dispersion of microtubule arrays and may affect microtubule alignment into parallel arrays (Nakamura and Hashimoto, 2009; Fishel and Dixit, 2013). In the ton 2 mutant, which shows reduced branching nucleation activity, transverse microtubule arrays failed to reorient into longitudinal arrays (Kirik et al., 2012), suggesting a possible causal relationship between branching nucleation and microtubule array reorientation. Here we tested the role of branching nucleation during 
hormone-induced microtubule reorientation into transverse arrays using long time-lapse imaging of microtubule nucleation events in wild type and in the ton 2 mutant. We have not found any changes in nucleation modes during microtubule reorientation process. Similarly, a recent report on light-induced microtubule reorientation also did not provide a strong support for the role of the microtubule branching nucleation in reorientation of microtubule arrays from transverse to longitudinal arrays (Lindeboom et al., 2013). Although a branching nucleation event forming a microtubule in new orientation was observed during the light-induced reorientation, the rate of microtubule branching nucleation actually decreased in the process of reorientation, suggesting that the reorientation mechanism is not driven by up-regulation in microtubule branching nucleation.

Microtubule arrays in the ton 2 mutants formed the same configurations as wild type and responded to IAA/GA4 hormone treatment by orienting transversely to the long cell axis. The reorganization process was less effective in the mutant due to a combination of a slower reorientation rate and an inability of arrays to reorient in some cells. Less efficient microtubule reorientation the ton 2 mutant may be caused by reduction in sensitivity or response to hormones. However the number of transverse microtubules appearing from cell sides increased about 3 fold both in wild type and in the ton2 mutant, suggesting that hormone sensitivity and response were not reduced in the mutant.

Rapid cell elongation has been shown to induce formation transverse microtubules (Sambade et al., 2012), suggesting that microtubule orientation into 
transverse arrays is a part of cellular response to rapid cell elongation, rather than being a licensing factor for commencing of anisotropic cell expansion. In the ton 2 mutant, the smaller number of transverse microtubules emerging from the transverse orthogonal walls under the hormone treatment conditions may be related to the inability of the ton 2 mutant to elongate rapidly. Indeed, cells of the ton 2 mutants are smaller in size, consistent with growth defects (Torres-Ruiz and Jürgens, 1994; Kirik et al., 2012). Thus, reduced efficiency of microtubule reorientation into transverse arrays in the ton 2 mutant supports the hypothesis that rapid cell elongation drives reorientation of microtubules into transverse arrays.

In the ton 2 mutant the frequency of transverse microtubules appearing from the longitudinal cell sides was 4 times lower than in wild type. This inability to produce enough side microtubules may lead to slower re-orientation rate in ton2 mutants. The molecular mechanism generating these transverse microtubules is not known. It was suggested that transverse microtubules form at the anticlinal sidewalls of cells by local increase in microtubule nucleation (Vineyard et al., 2013). As branching nucleation is the only microtubule nucleation mode reduced in the ton 2 mutant, it is tempting to speculate that branching nucleation contributes to the formation of pioneering transverse microtubules. However, both in wild type and in the ton 2 mutant hormones increases the frequency of the transversal microtubules without an increase in the proportion of branching nucleation, casting a doubt on the role of branching nucleation as a primarily generator of discordant microtubules. Other nucleation types, parallel and de-novo, also did not increase at the periclinal cell surface during the hormone treatment. Consistent with previous observations, our data suggest that the mechanism generating discordant 
transverse microtubules is not active at cells' periclinal surface, but rather is activated on the longitudinal orthogonal surface of the cell (Sambade et al., 2012; Vineyard et al., 2013). Our data, however, cannot exclude the possibility that microtubule nucleation is a part of the reorientation mechanism that locally upregulates formation of new microtubules at longitudinal side walls of hypocotyl cells.

Presented here results show that, despite a lower proportion of branching nucleation and reduced microtubule stability, most ton 2 mutant cells can still respond to the IAA/GA4 hormonal signal and initiate microtubule reorientation. Our data show that TON2 function is required for efficient reorientation by supporting the formation of transverse microtubules emerging at the antilcinal faces. It has been shown that microtubule density is $27 \%$ in the hypocotyl epidermal cells of the ton 2 mutant (Kirik et al., 2012). The origin of the pioneering transverse microtubules during hormone-induced reorientation is unknown, but the density of pre-existing polymers is likely to play an important role in several possible mechanisms. For example, pre-existing microtubules can provide a surface for binding of the $\gamma$-TURC nucleation complexes and can form microtubule crossovers, inducing severing and formation of new microtubule plus ends. Transverse microtubules were shown to be present at the longitudinal anticlinal walls even in cells with longitudinally oriented arrays at the periclinal cell surface (Chan et al., 2009). In this scenario, efficient generation and spreading of discordant transverse microtubules during the reorientation process will be dependent on the microtubule density and, consequently, ton 2 mutants will not be able to generate transverse microtubules at high frequency due to their lower density of microtubules. 
Discordant side microtubules appear from the longitudinal cell sides, suggesting that microtubule reorientation may be triggered by cell polarity signals. It is conceivable that the hormone auxin, which is known to polarize plant cells during development, may change cell polarity and growth direction of the hypocotyls cells when applied exogenously. Gibberellic acid is known to promote cell elongation (Shibaoka, 1974; Shani et al., 2013). Therefore directional cell expansion itself may provide a signal changing cell polarity and ultimately stimulating the formation of microtubules at the longitudinal anticlinal walls.

Addressing molecular mechanisms that generate transversal microtubules in response to hormones will be a key to understanding how microtubule reorientation is triggered. To shed light on the mechanism triggering microtubule reorientation, it will be important to develop microscopy techniques that will allow resolution of individual microtubules at the anticlinal cell surface to test for changes in microtubule nucleation rates and local dynamic properties of microtubules during the reorientation process. 


\section{CHAPTER II}

\section{POK/TON2 INTERACTIONS}

\section{Introduction}

Phragmoplast orienting kinesin1 (POK1) is a protein that promotes the alignment of the phragmoplast with the division site previously occupied by the PPB (pre-prophase band, Müller et al., 2006). The phragmoplast is the structure that serves as a scaffold for the cell plate, and later the cell wall, formation. POK is believed to be involved in guiding the expanding phragmoplast to the cortical division site to ensure proper orientation of the cell division plane. POK is also thought to be involved in phragmoplast guidance by controlling microtubule interactions between the nucleus and the cortex (Müller et al., 2006). The PPB is the band of former interphase microtubules that form a hoop at the future plane of cytokinesis. At mitosis, microtubules arrange into the mitotic spindle, which is subsequently transformed into the phragmoplast during late telophase (Müller et al., 2006).

POK1 was found to localize as ring structures on the cell cortex in dividing cells starting in prophase, where there is a PPB, through the cell cycle with spindle and phragmoplast formation (Lipka et al., 2014). The pok double mutant seedlings have phenotypes of smaller short, swollen roots, smaller cotyledons and smaller hypocotyls, 
while adult plants are dwarfed and fertile, though less seeds are produced than wild type plants (Müller et al., 2006). Roots also show disordered cell division planes in the double mutant. POK1 and POK2 are redundant genes so mutants must be homozygous to see the phenotype (Müller et al., 2006). Phragmoplasts in the double mutant do not line up properly with the PPB; they are tilted in relation to the transverse axis (Lipka et al., 2014). This tilting of the phragmoplast lead to improper cell division planes and an increased the amount of time it took to complete cytokinesis, which is believed to be due to the slowed expansion rate of the phragmoplast (Lipka et al., 2014).

It has been found that the POK proteins act downstream of PPB formation and the determination of the cell division plane. It accumulates in the cytoplasm during prophase and then associates with the cortical division zone for the rest of mitosis and that this recruitment of POK1 to the cortical division zone is a microtubule dependent process (Lipka et al., 2014). During metaphase, after the PPB has been broken down, POK1 is immobilized so that its area of localization, the cortical division zone, begins to narrow to the cortical division site, this narrowing continues through the rest of mitosis until the cell plate fuses with the parental plasma membrane (Lipka et al., 2014). There are two main theories about how POK1 is functioning: 1) it binds directly to the outer microtubules of the phragmoplast and may use a motor domain to guide the phragmoplast (though the motor activity of POK has not been studied), or 2) POK1 may act with other proteins to stabilize the outer phragmoplast microtubules as they move toward the plasma membrane to make the new cell plate (Lipka et al., 2014). 
This study aimed to look at POK and TON2 interactions by looking at POK timing using a Cyclin B1 and an YFP: TUA5 line to determine which stage of the cell cycle the cell is in. It was found that POK and TON2 presence overlaps in the beginning of the cell cycle. The study also aimed to look at whether POK and TON2 act in the same pathway. Our data suggests that they could work in the same pathway, but more data is needed to verify this.

\section{Results}

Recently it was found that POK1 acts in the same place that the PPB previously inhabited (our own observations; Lipka et al., 2014). It is unknown how POK would work if the PPB never formed. The ton 2 mutant is incapable of forming a PPB so it is unclear if the POK1 protein will be able to localize to the cortical region of the division site when there is no PPB to act as its guide. It was also unknown if POK1 promotes TON2 function.

One of the first steps we took was to look at timing of POK localization. To do this we crossed an already established $\mathrm{TP}_{1}$-tdTOM-POK line (tdTOM is a red fluorescent protein) with a cyclin B1 line that has a green fluorescent protein (GFP) tag. Cyclin B1 is a cell cycle protein; it is active during the early stages of mitosis (prophase and metaphase) and is degraded during anaphase and telophase. Using the spinning disc confocal microscope we took images at 0,10 , and 20 minutes to observe dividing root cells as they go through the cell cycle (Figure 6). The appearance of the POK protein coincided with the times when the PPB would be present. 

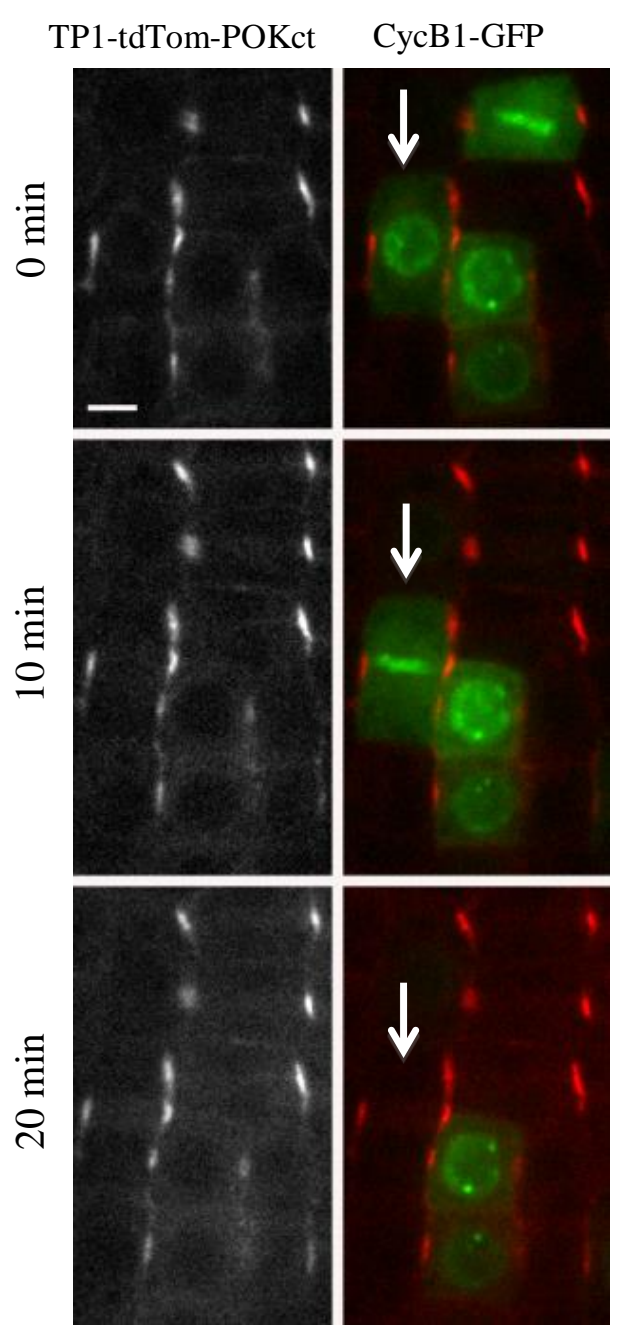

Figure 6. POKct signal in wild type plants with a Cyclin B1 - GFP marker at 0, 10, and 20 minutes to show cell cycle timing of POK localization. POK becomes visible when the PPB would be in the cell (prophase) all the way through the end of the cell cycle. This can be seen by following the cell with the arrow. The CyclinB1 signal is gone from the 20 minute panel because the cell had entered anaphase/telophase and CyclinB1 is no longer expressed during those phases of the cell cycle. The signal in the left panels is $\mathrm{TP}_{1^{-}}$ tdTOM-POK signal. The red signal in the right panels is POK, green is CyclinB1 fused to GFP. Scale bar is $100 \mu \mathrm{m}$. Arrow points to the same cell. Images taken together with Dr. Kirik. 
We next wanted to look at whether POK still localizes to the former PPB location in ton 2 mutants, where the PPB is not formed. To do this, we crossed YFP-TUA5 (a microtubule marker fused with yellow fluorescent protein) into the $\mathrm{TP}_{1}$-tdTOM-POK transformed into the ton 2 mutant background (already established by the lab). We then used the spinning disc confocal microscope to image both wild type and ton 2 mutant plants, looking for POK localization. The YFP-TUA5 marker allowed us to determine which cell cycle stage the cell was in so we would know if the PPB/POK should be visible (Figure 7). In wild type cells POK localized to the previous PPB site, as expected (Figure 7a). This can be seen in the middle cell of Figure 7a, where the cell is in prophase, as seen in the microtubules surrounding the nucleus. The outer two cells in Figure $7 \mathrm{a}$ are at the late stages of cytokinesis and forming phragmoplasts, the most left cell has an early stage phragmoplast while the right most cell has a late stage phragmoplast. In contrast, when observed in the ton 2 mutant no POK signal was observed at all (Figure $7 \mathrm{~b}$ ). In the ton 2 mutant a cell in prophase can be seen in the upper right of the panel, but no POK signal is visible (Figure $7 \mathrm{~b}$ upper cell). The other dividing cell visible is in the late stages of cell division with a phragmoplast and there is still no POK signal visible (Figure 7b, lower cell). 

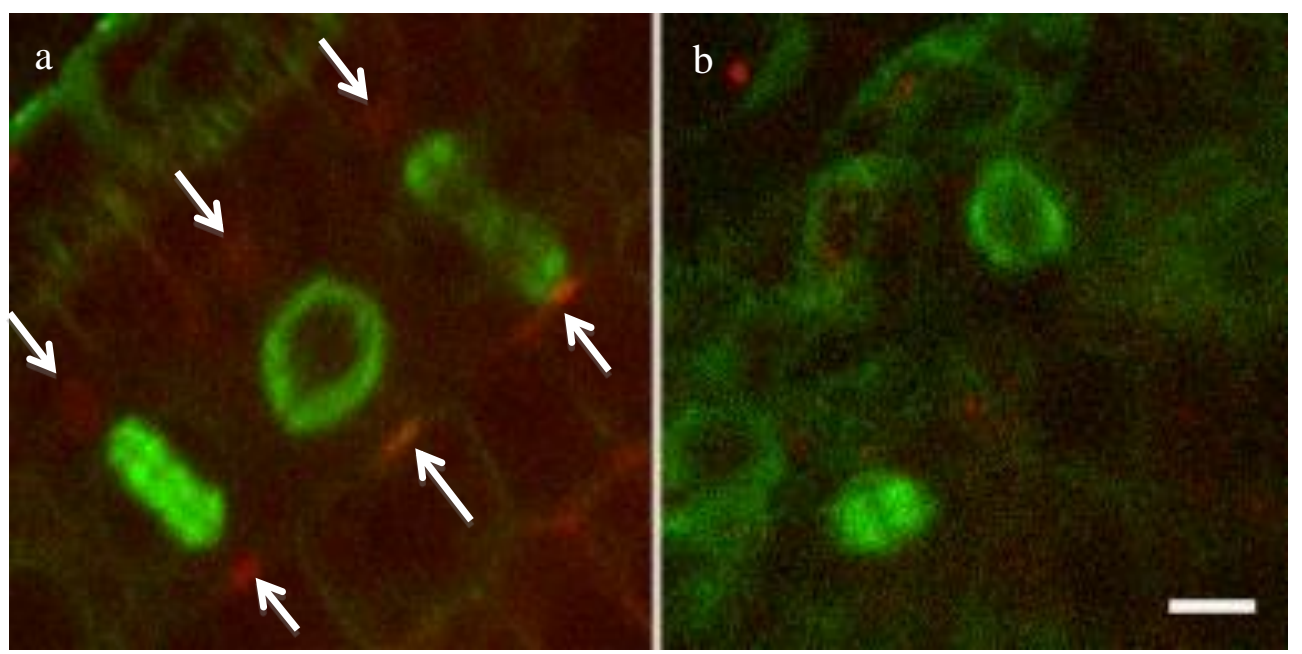

Figure 7. POK localization using YFP: TUA5. TP1-tdTom-POK transformed into ton $2 \mathrm{x}$ YFP-TUA in a) wild type and b) ton2 mutant. Notice the lack of POK signal in dividing ton 2 mutant cells (b) compared to clear signal in wild type (a) shown with arrows. Red dots seen in (b) are artifact and not a true signal. Scale bar is $100 \mu \mathrm{m}$.

Images were taken together with Dr. Kirik. 
After seeing no POK signal in the ton 2 mutant we grew the ton 2 plants in soil, along with wild type and controls, to verify our results by isolating DNA from the plants. DNA was isolated from four ton 2 plants, a wild type plant negative for tdTOM signal (put positive for YFP signal), a wild type plant with TdTOm:POK construct, and a plant without any POK or YFP tags. The kanamycin resistance was conferred by the POK plasmid and was a selective tool to ensure we chose plants with the tdTOM-POK construct. After isolating the plasmid and performing PCR reactions with different primer combinations it was seen that the POK gene was present in the ton 2 mutant and wild type plants except in one of the ton 2 plants, which didn't segregate the gene, and the control DNA that didn't have any POK or TUA markers (Figure 8). Lanes A1 and A7 have a band because $\mathrm{TP}_{1}$ present in all Arabidopsis thaliana plants making it a positive control (Figure 8). Lane B1 (a ton2 mutant plant) did not have a band meaning that the construct with the $P O K$ gene did not segregate in this ton 2 mutant plant. 


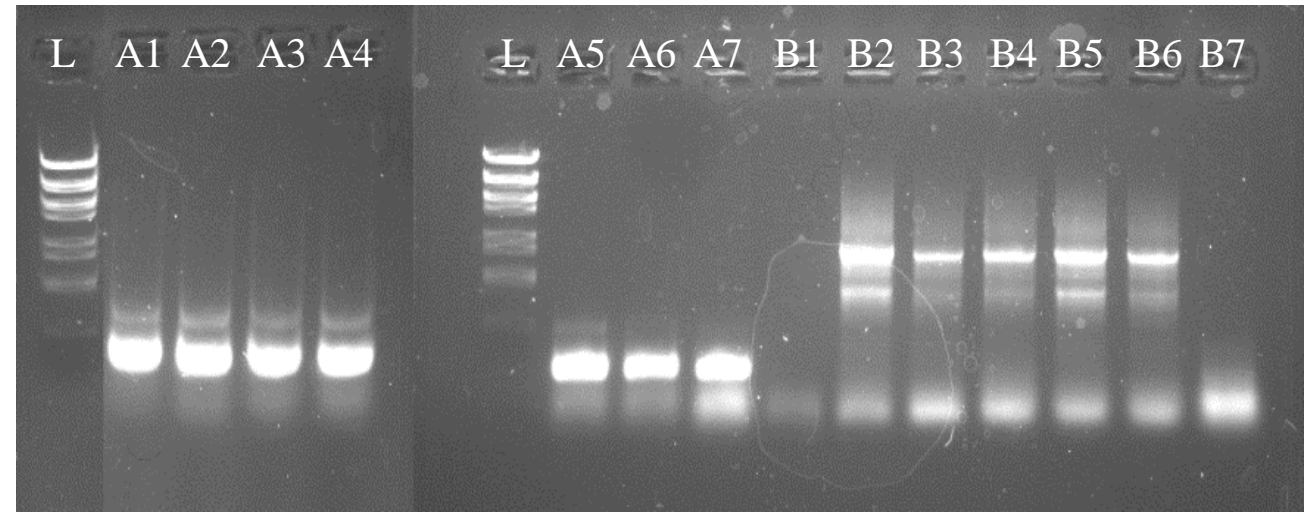

Figure 8. Gel verification of POK presence.

Lanes L: $\lambda$-DNA/Eco91I ladder (Fermentas)

Gel showing that the $P O K$ gene is in the plants that DNA was isolated from. Lanes designated with an A are PCRs run with primers for the $\mathrm{TP}_{1}$ promoter used in the $\mathrm{TP}_{1}$-tdTom-POK construct. All lanes are the correct expected band size of $\sim 350 \mathrm{bp}$. Lanes designated with a B are PCRs run with the $\mathrm{TP}_{1}$ sense primer and the tdTOM AscI antisense primer. Lanes B2-6 show the correct band size of $\sim 1.8 \mathrm{~kb}$.

1: ton2 plant 1; 2: ton2 plant 2; 3: ton2 plant 3; 4: ton2 plant 4; 5: Wild type tdTOM negative, YFP positive; 6: Wild type kanamycin resistant plant; 7: Wild type DNA without POK and TUA tags. 
The last test we did to test the interactions between ton 2 and POK was genetic crosses. We crossed all different allele combinations of the two genes to each other to test their phenotypes (Table 1). Since the ton 2 mutation is a sterile mutation we had to grow each line and select plants that segregated the ton 2 mutation before continuing forward with looking at the cross.

\begin{tabular}{|c|c|}
\hline \multicolumn{2}{|c|}{ Table 1: Genetic crosses done with ton2 and pok mutants } \\
\hline Mother plant & Father plant \\
\hline Pok $_{1-2}$ pok $_{2-1}$ (weak mutant) & Ton2-15 (weak allele) \\
\hline Ton2-15 \#2-1 (weak allele) & Pok $_{1-2}$ pok $_{2-3} \# 3-3$ (strong allele) \\
\hline Ton2-13 \#6-7 (strong allele) & Pok1-2pok2-1 (weak mutant) $^{2}$ \\
\hline Ton2-13 \#6-4-1 (strong allele) & Pok $_{1-2}$ pok $_{2-3} \# 3-4-1$ (strong allele) \\
\hline
\end{tabular}

We then grew the crosses on $1 \%$ sucrose plates and looked at phenotypes after 7 days after germination (Figures $9 \& 10$ ). The image in figure 9 shows that the strong POK allele $\left(\operatorname{pok}_{1-2} \operatorname{pok}_{2-3}\right)$ has a shortened root that is similar to the root of the weak ton2 allele mutation (ton2-15; Figure $9 \mathrm{~b} \& \mathrm{c}$ ). The double mutant's root is severely shortened even compared to the two single mutants, whose roots are already shortened (Figure 9). 


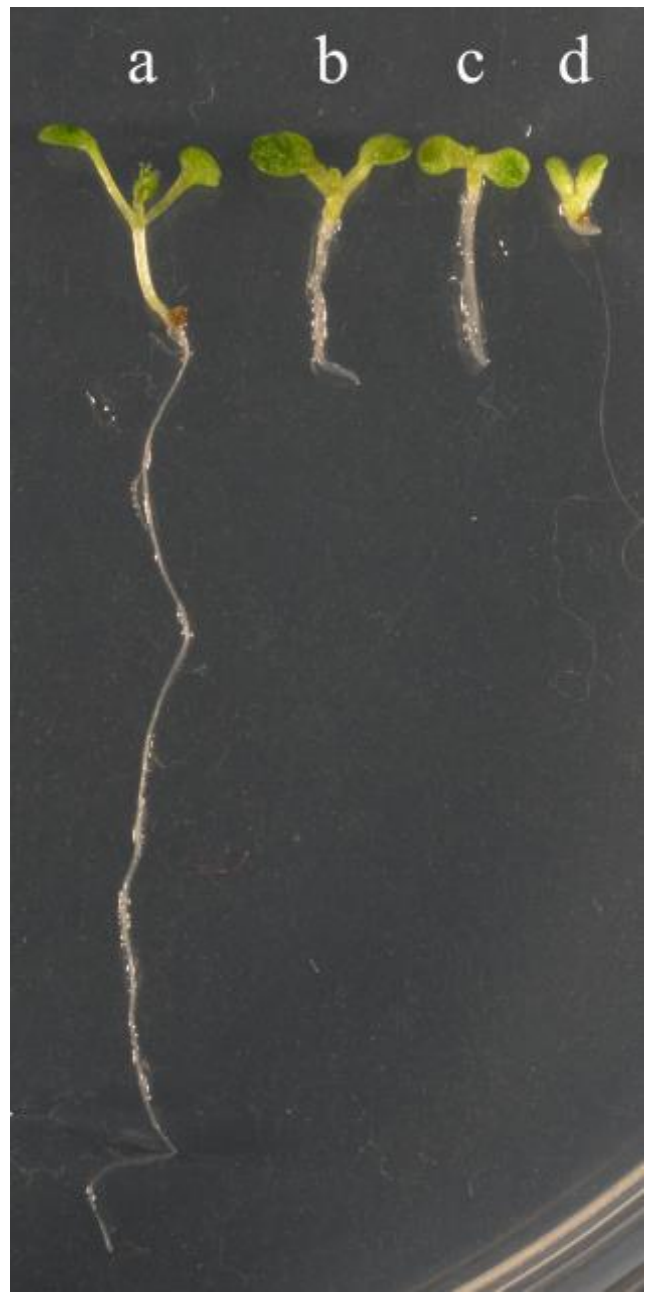

Figure 9. Weak ton2 $\mathrm{x}$ strong pok.

Comparison of root and plant

development of wild type, individual

mutants, and double mutant from the F2

ton2-15\#2-1 x pok 1-2 pok $_{2-3} \# 3$-3 line \#10.

a) Wild type, b) pok pok $_{2-3}$, c) ton2-15,

d) double mutant. 
In the weak TON2 allele and weak POK mutant combination, we can see that the double mutant's root is shortened even compared to the two single mutants, whose roots are already shortened (Figure 10). In this case, the weak POK mutations ( Pok $_{1-1}$ pok $\left._{2-1}\right)$ cause a less severe shortening of the root than the strong POK mutations ( pok $_{1-2}$ pok $_{2-3}$; compare Figure $9 \mathrm{~b}$ to $10 \mathrm{~b})$.

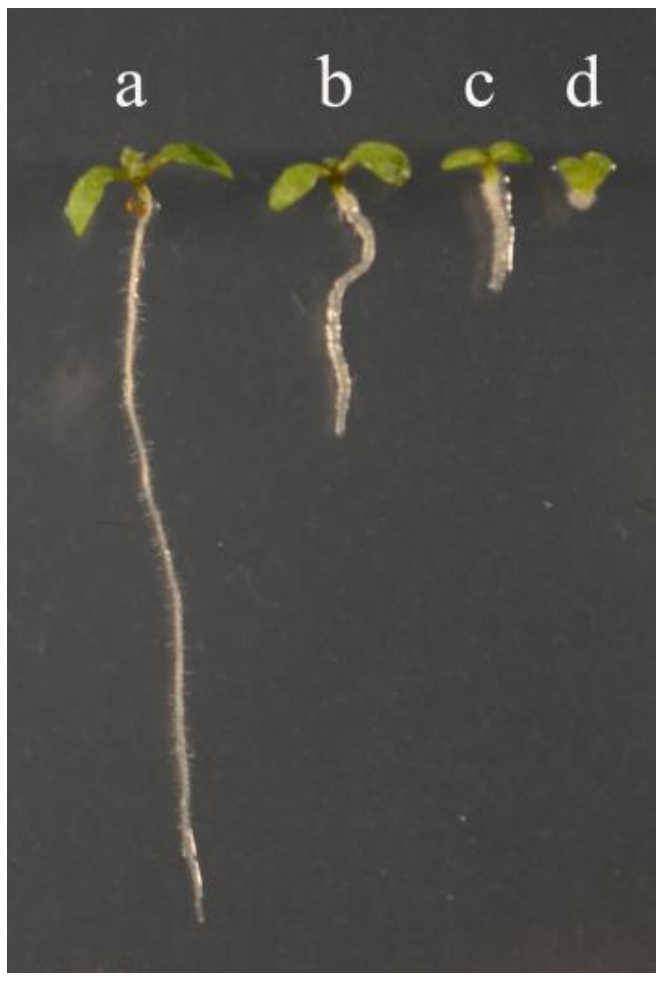

Figure 10. Weak pok x weak ton2. A comparison of root and plant development in wild type, individual mutants, and double mutant plants from the $\mathrm{F} 3$ pok $_{1-2}$ pok $_{2-1} \mathrm{x}$ ton215 line. a) Wild type, b) pok1-2pok2-1, c) ton2-15, d) double mutant. 


\section{Discussion}

From our images we can see that the POK protein appears at the same time that the PPB is present in the cell. We can also see that POK is not present in the ton2 mutant, which does not form a PPB. This leads us to the question of how TON2 and POK interact. From the lack of proper localization of POK in the ton 2 mutant we believe that TON2 is needed for proper POK localization or stability.

The phenotype images we have taken support this idea that POK is dependent on TON2. The strong/weak crosses' phenotypes lead us to believe that TON2 is epistatic to POK. We cannot claim this as a certainty because we are waiting on the next generation of strong TON2 allele crosses to verify our beliefs. The combinations of the two genes result in phenotypes more similar to the ton 2 mutant phenotype, swollen roots with thicker cotyledons. We have all mutations segregating in the F2 generation, but we could not distinguish double mutant phenotypes in the crosses with the strong TON2 allele in this generation. The strong TON2 allele is severely shortened to the point of looking like a nub on the end of the hypocotyl. In order to find double mutants we are going into the next (F3) generation.

There are future project opportunities that could help further elucidate the interactions between POK and TON2. We have looked at the localization of POK in the ton2 mutant, but the opposite still needs to be done. How is TON2 localization affected in the pok1-2pok2-3 double mutant? Also, looking at the localization of YFP-POK1 in cells where TON2 is targeted to the plasma membrane will help explain the interactions 
between the two proteins. If TON2 is mistargeted to the plasma membrane will POK also become mistargeted to the membrane or not align properly with the PPB? 


\section{CHAPTER III \\ RIC1 EFFECT ON CELL SHAPE}

\section{Introduction}

Arabidopsis epidermal (pavement) cells on leaves normally have a puzzle piece arrangement with lobes and necks interlocking with each other. Cortical microtubule bundles in the neck regions are well ordered and are arranged transversely to restrict growth in their direction of orientation, meaning they stop necks from getting wider (Wasteneys and Galway, 2003; Fu et al., 2005). Lobe formation requires cortical actin microfilaments that are localized to sites that lack the before mentioned microtubules (Frank and Smith, 2002; Fu et al., 2002, 2005). RIC1 (ROP-interactive CRIB motifcontaining proteins) is an effector protein for the Rho GTPase, ROP6, that interacts with the active form of the ROP6 through the CRIB domain (Wu et al., 2001; Fu et al., 2005, 2009). RIC1 is involved in the organization of cortical microtubules (Ueda et al., 1999; Fu et al., 2002, 2005, 2009). It promotes organized cortical microtubules which are transverse to the elongation axis and permit growth perpendicular to their orientation $(\mathrm{Fu}$ et al., 2009). RIC1 promotes microtubules in the necks of cells. RIC1 also inhibits the pathway that induces lobe formation by repressing ROP2 activation (Fu et al., 2005). Areas of lobe formation contain fine microfilaments, but no cortical microtubules associated with the neck regions of cells (Fu et al., 2009). Hormone signaling has been 
shown to be involved in the ROP6-RIC1 pathway, specifically the hormone auxin (Xu et al., 2010). It has been proposed that the Auxin Binding Protein1 (ABP1) is a receptor that activates cell expansion (Jones, 1994; Chen et al., 2001; Badescu and Napier, 2006; Xu et al., 2010). ABP1 is anchored to the outside of the plasma membrane by a GPIanchored protein and it is believed to work with an unknown transmembrane protein to transfer the auxin into the cell (Jones et al., 1998; Chen et al., 2001; Xu et al., 2010). A mechanism has been proposed that auxin interacts with ABP1 which leads to ROP6 activation, which leads to RIC1 activation which leads to the organized cortical microtubules (Xu et al., 2010).

Other studies have tried to determine how RIC1 is controlling the well-ordered cortical microtubules. A recent study has found that RIC1 interacts with the microtubule severing protein katanin (KTN1) which severs the minus ends of branching microtubules, detaching them from the mother microtubule (Lin et al., 2013). They show that RIC1 and KTN1 localize to the overlapping locations and that RIC1 promotes the activity of KTN1 by physically interacting with KTN1 (Lin et al., 2013). For cell elongation to occur the cortical microtubules need to be in parallel, aligned arrays and microtubule severing was proposed to promote this by severing the branching microtubules that weren't aligned with the array (Burk et al., 2001; Shaw et al., 2003; Murata et al., 2005; Nakamura and Hashimoto, 2009; Xu et al., 2010). RIC1 has been shown to regulate KTN1's activity and therefore promote the well-ordered microtubule array (Lin et al., 2013). This study added another piece in the puzzle of how the ROP6-RIC1 signaling pathway controls microtubule organization; auxin activates ABP1 which activates ROP6 which activates 
RIC1 which positively regulates KTN1's ability to sever microtubules so that they can be rearranged into an ordered array (Xu et al., 2010; Lin et al., 2013).

It was shown that over-expression of RIC1 made necks smaller and mutating RIC1 made necks wider and lobes larger (Fu et al., 2005). It is this phenotype that made RIC1 an interesting gene to study. It has been shown to have a phenotype identical to that of PM-TON2 (Figure 11; Kirik et al., 2012). PM-TON2 altered plants so that TON2 is expressed on the plasma membrane instead of its usual location, leading to the question of whether RIC1 acts in the TON2 pathway (Kirik et al., 2012). 


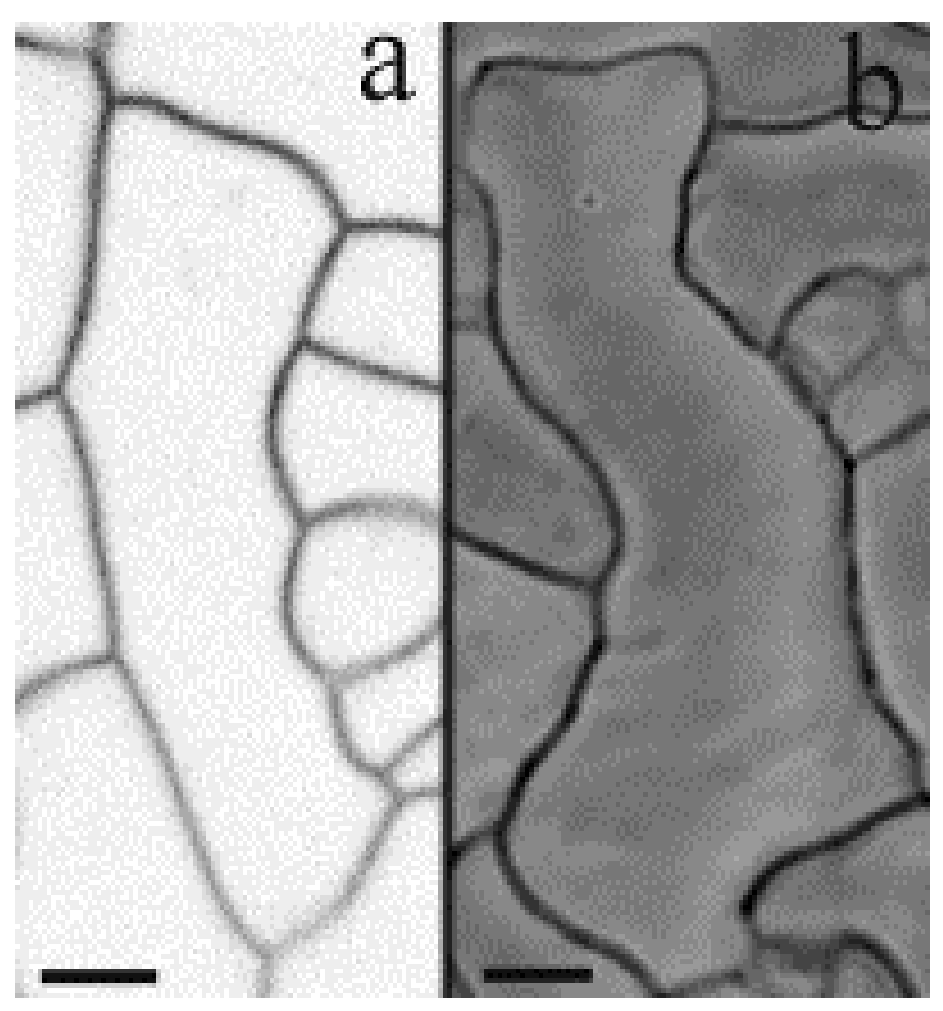

Figure 11. PM-TON2 and RIC1 overexpression comparison. Leaf with a) TON2 mislocated to the plasma membrane (PM-TON2) imaged using the spinning disc confocal microscope and b) RIC1 over expression line imaged using the fluorescent microscope. Notice the similar shape of long cells without lobes. Scale bars are $100 \mu \mathrm{m}$ and $25 \mu \mathrm{m}$ respectively. PM-TON2 image (a) was taken previously by Dr. Kirik. 


\section{Results}

To determine if TON2 acts in the same pathway with RIC1/Rho GTPase, RIC1 over expression lines and the ricl-1 mutant have been crossed into the ton 2 mutant background. The plants were grown on $1 \%$ sucrose $1 / 2 \mathrm{MS}$ general media (GM) plates for 8 days and then their cotyledons were used to make impressions. To make impressions, the cotyledons were cut from plant and placed into molten 3\% agarose GM media that had been melted and poured into a mini petri plate. The media was then allowed to solidify and the cotyledons were peeled off and the impression was viewed under the fluorescent microscope (Figure 12). 


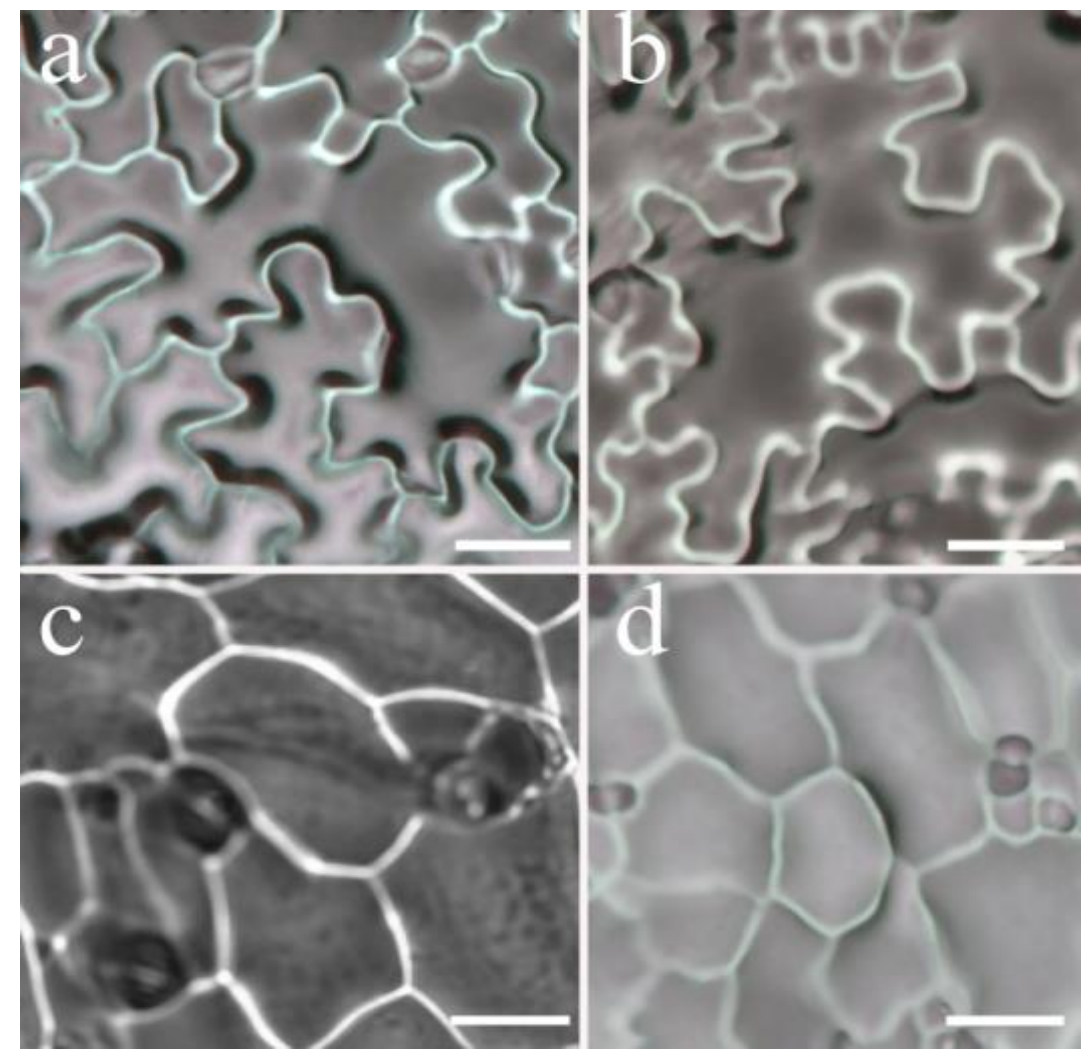

Figure 12. Comparison of pavement cells in different cell lines. Note the similarity of phenotype of the ton 2 mutant (c) and the double mutant ric $_{1-1}$ ton2 (d). a) Wild type, b) ric l-1 $_{1}$ mutant, c) ton2 mutant, d) ric $c_{1-1}$ ton2 double mutant. Scale bar is $50 \mu \mathrm{m}$. 
RIC1 affects microtubules in the necks of cells and inhibits lobe formation (Fu et al., 2009) so these are the areas that we wanted to look at while analyzing our images (Figure 13).

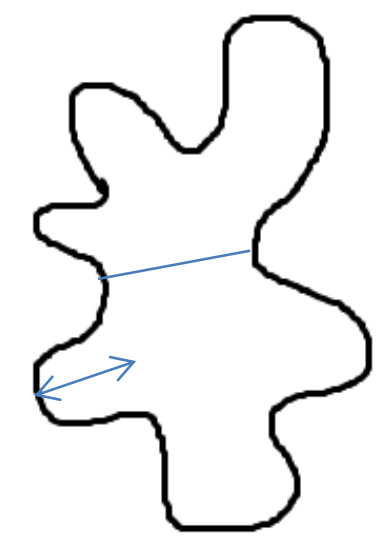

Figure 13. Schematic of a wild type cell impression. The double arrowhead line indicates an example of a lobe while the line with no arrowheads shows an example of a neck. 
When analyzing the images we found that wild type had an average lobe length of $17.3 \mu \mathrm{m}$, the ton 2 mutant had an average lobe length of $11.7 \mu \mathrm{m}$, ric $_{1-1}$ mutant had an average lobe length of $22.1 \mu \mathrm{m}$, and the ric $_{1-1}$ ton 2 double mutant had an average lobe length of $9.2 \mu \mathrm{m}$ (Figure 14). The ton 2 mutant and ric $_{1-1}$ ton 2 double mutant cells both lacked lobes or had very small lobes.

When analyzing the images we found that wild type had an average neck length of $29.2 \mu \mathrm{m}$, the ton 2 mutant had an average neck length of $45.3 \mu \mathrm{m}$, ric $c_{1-1}$ mutant had an average neck length of $31.1 \mu \mathrm{m}$, and the ric $_{1-1}$ ton 2 double mutant had an average neck length of $43.5 \mu \mathrm{m}$ (Figure 14). The ton 2 mutant and ric $_{1-1}$ ton 2 double mutant cells both had necks that were very large when compared to the wild type and $r i c_{1-l}$ mutant. 


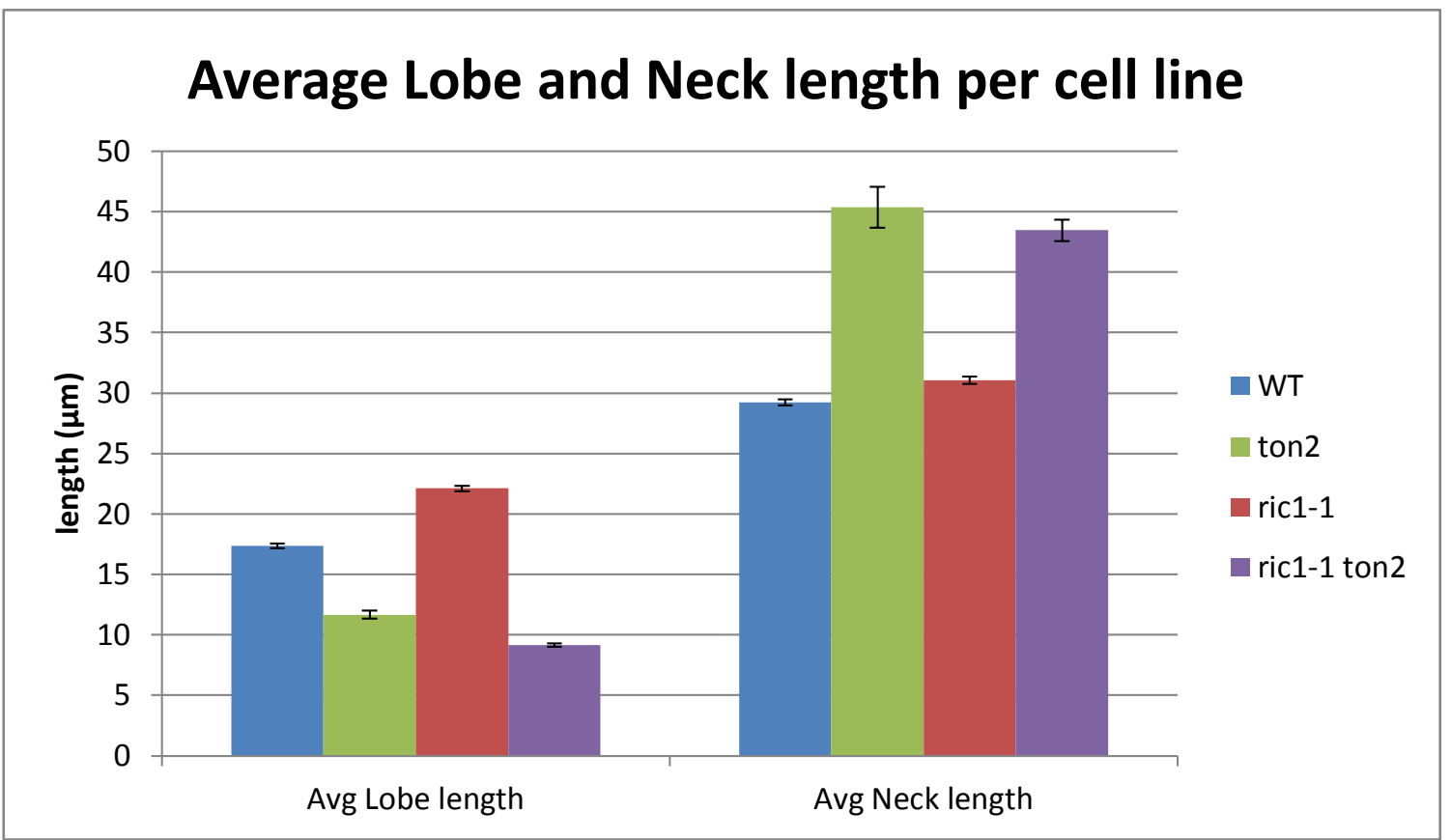

Figure 14. Average lobe and neck length per cell line. Graph comparing the average lobe and neck lengths of pavement cells for the different cell lines. $n=11$ cotyledons for wild type, 6 cotyledons for ton 2, 12 cotyledons for ric $_{1-1}$, and 8 cotyledons for ric $_{1-1}$ ton2 double mutant. Error bars show standard error of mean. 


\section{Discussion}

Our data show that the double mutant (ric ${ }_{1-1}$ ton2) phenotype was the same as the ton 2 mutant alone (ton 2-15), consistent with ton 2 being epistatic to ric 1 -1, but other explanations are possible. This can be seen when looking at the impressions images, the double mutant images have the same rounded cells with few or no lobes that the ton 2 mutant cells have. It can also be seen when the lobes and necks' sizes are compared. The lobes and necks of the wild type and ric $_{1-1}$ mutant are similar, while the ric $c_{1-1}$ ton2 double mutant shares similar lobe and neck sizes with the ton 2 mutant. This could mean that $R I C 1$ is dependent upon TON2 being present, but without the RIC1 overexpression lines we cannot say for sure if this is the case. If RIC1 is dependent upon TON2 it could need to be dephosphorylated by TON2 (since TON2 is a phosphatase) to form proper necks and inhibit lobes.

We were unable to compare lobe/necks for the RIC1 over expression line because we were unable to establish homozygous over expression lines. The cross had previously been done in the lab and we were unable to find homozygous lines (100\% Basta resistance) that still showed the over expression phenotype of under-branched trichomes and still segregate the ton 2 mutant. We saw that if the line was homozygous for RIC1 overexpression the line did not segregate the ton 2 mutant. To try to overcome this hurdle we have RIC1 in a construct that has an ubiquitin promoter that we will be transforming into a TON2 heterozygous line. Hopefully this approach will allow us to find RIC1 overexpression lines that still segregate the ton 2 mutation. 
To further elucidate the interaction between TON2 and RIC1 we plan to look at RIC1's effect on plasma membrane targeted TON2. To look at the effect of RIC1 on PM-TON2 we will introduce the dexamethasone (DEX) inducible PM-TON2 line into the RIC1 background. We would then induce PM-TON2 with DEX and see how the phenotype of the pavement cells would change. Is PM-TON2 using Rho GTPases to suppress lobe formation? Also, we want to look at the localization of RIC1 in the ton2 mutant. To do this we want to transform a GFP-RIC1 construct into a TON2 heterozygous line with a cherry microtubule marker and use the confocal microscope to see if RIC1 is localized along microtubules in both wild type cells and ton2 mutant cells. 


\section{CHAPTER IV}

\section{METHODS}

\section{Plant Growth Conditions}

All plants were grown in a plant growth chamber at 22 degrees Celsius or in a greenhouse at room temperature. The growth chamber was an Intellus Environmental Percivall incubator that has a day/night cycle of 16 hours day/light and 8 hours of night/darkness. When grown on plates, seeds were sterilized with a series of $70 \%$ ethanol and autoclaved deionized water washes and grown on half strength Murashige and Skoog (MS) media, with $5.5 \mathrm{~g} / \mathrm{L}$ agar and a $\mathrm{pH}$ of 5.6. If antibiotics were added they were diluted to working concentrations in the half MS media. Columbia was used as the wild type. When grown on soil or transferred to soil, plants were grown on a one to one ratio of Sunshine Redi-earth Professional growth mix and Pro-Mix HP mycorrhizae High Porosity growing medium.

\section{Plant Transformation}

Plants' transformations were performed using the flower dip protocol (Bechtold et al., 1993). In summary, plants were grown with six plants per four inch pot until they had started budding. The desired constructs were transformed into a GV3101 strain of Agrobacterium. 
Then $100 \mathrm{ml}$ of YEB with the antibiotics corresponding to the plasmid being transformed was inoculated with the Agrobacterium and grown at 28 degrees Celsius for 48 hours in the shaker. The cells were then centrifuged at 4000rpm for 10 minutes. While spinning the infiltration medium was made, which was a 5\% sucrose and $0.05 \%$ Sillwett-77 solution. The supernatant was discarded and the pellet was resuspended in $200 \mathrm{ml}$ of the infiltration medium. Plants were then dipped in the infiltration medium for 20 seconds per pot and placed on their side in a tray with dampened paper towels to increase the humidity. The tray was covered overnight and moved to the greenhouse the next day and uncovered.

\section{Microscopy}

For live cell imaging a spinning disk confocal microscope with a Leica DM600 inverted microscope was used along with a Yokogawa CSUX-M1 confocal scanner (high speed version) and a Photometrics Evolve 512 camera. For spinning disc confocal microscopy, 488nm and $561 \mathrm{~nm}$ wavelength lasers were used. In hormone treatment imaging, the $488 \mathrm{~nm}$ exposure was $900 \mathrm{~ms}$ and the $561 \mathrm{~nm}$ exposure was $400 \mathrm{~ms}$ at a neutral density attenuation of 11 using an 100x oil immersion objective. The time - lapse imaging was performed in 6 second intervals for a total of 900 time points. SlideBook 5.0 for Windows XP/Vista/x64 was the computer software used to view the live cell imaging and take the image. Image J was used to analyze the images (see below).

Light microscopy was done using a Leica DMRBE microscope and the Leica DFC300FX digital CCD camera. The dissecting scope was used for the POK/TON 
interaction images. A Leica digital camera was used for zoomed out images of POK/TON interaction plants.

\section{Impressions of Epidermis}

Impressions of eight day old cotyledons were made using 3\% agarose. The agarose was heated and poured into $3.5 \mathrm{~cm}$ petri dish and cotyledons were carefully cut from the plant using a dissecting microscope and a needle. The leaves were then placed on top of the molten agarose so that the top of the leaf was in contact with the agarose. The agarose was then allowed to completely solidify, about 10 minutes. Before imaging with the light microscope, the cotyledons were peeled from the agarose and then the microscopy was completed.

Images were taken in a series so that the entire field of view was imaged with different areas in focus. Then the images were compiled into a complete in focus image using Helicon Focus software. Images were then analyzed with ImageJ (see below).

\section{Image J}

For analyzing microtubule reorientation/ nucleation images we used the subtract background plugin with the rolling ball algorithm with a rolling ball radius of 50.0 pixels. We then merged the channels and assigned them colors $\left(\mathrm{GCP}_{2}\right.$-GFP as green and mCherry TUA5 as red). The program was then used to scroll through the frames and find nucleation complexes. When one was found we marked it with an ROI so that it could be referred to specifically again. Z projections were also made of the types of nucleations. 
To do this we used the Z-projection plugin in the stacks menu. A Z-projection SUM of the desired frames was used.

To make movies of the different nucleation complexes in action first a substack was made of the frames specifically showing the nucleation. Then the QuickTimeMovie plugin was used to make the video. The compression type was Sorenson with high quality and 2 frames per second as the frame rate.

ImageJ was also used with the lobe/neck images of the RIC1 experiment. The images were opened in ImageJ (after using Helicon Focus to combine the images) and using the line tool we would draw a line from the apex of the lobe to the base or across the neck of the cell. We would then mark the line as an ROI so that it could be referenced later. We also measured the length of the neck/lobe using the measure tool in the program.

\section{DNA Isolation}

Two to three small leaf samples were put in $1.5 \mathrm{ml}$ tubes and either frozen in the minus 80 degree freezer and then flash frozen in liquid nitrogen or flash frozen in liquid initially and worked with immediately. A pestal was then dipped in liquid nitrogen to freeze it and a tube was removed and the leaves were ground until the leaves just began to warm (turn a dark green). Then $500 \mu \mathrm{m}$ extraction buffer* was added. These steps were repeated for two other tubes. Then, beginning with the first tube, the leaves were ground a second time until very fine pieces and placed on ice. This was repeated until all samples were ground. The tubes were then placed in the thermal mixer at 65 degrees Celsius for 20 minutes (without shaking). Then $500 \mu \mathrm{m}$ chloroform: iso-amyl alcohol 
mix (24:1) was added and the tubes were mixed for 5 seconds by inverting and spun at $12,000 \mathrm{rpm}$ for 10 minutes. The tubes were returned to ice and $400 \mu 1$ of the supernatant were transferred to a new $1.5 \mathrm{ml}$ centrifuge tube. Then $1 \mathrm{ml}$ of cold $95 \%$ ethanol $(\mathrm{EtOH})$ was added and the tubes were mixed by inverting until DNA "strings" were seen. Again the tubes were spun at $12,000 \mathrm{rpm}$ for 15 minutes and then returned to ice and the supernatant was carefully removed. Then $400 \mu \mathrm{m}$ of frozen $70 \% \mathrm{EtOH}$ was added and the tubes were spun at 12,000rpm for 2 minutes. The tubes were then returned to ice and the supernatant was again removed. The tubes were left open to air-dry and then the pellet was resuspended in $40 \mu 1 \mathrm{ddH}_{2} \mathrm{O}$.

*The extraction buffer was a 1:1 mix of buffers one and two in the tables below:

\begin{tabular}{|l|l|l|l|}
\hline \multicolumn{4}{|c|}{ Table 2: DNA isolation buffers } \\
\hline \multicolumn{2}{|c|}{ Buffer 1 (0.5L) } & \multicolumn{2}{c|}{ Buffer 2 (0.5L) } \\
\hline $0.35 \mathrm{M}$ Sorbitol & $31.9 \mathrm{~g}$ & $200 \mathrm{mM}$ Tris, $\mathrm{pH} 8.0$ & $100 \mathrm{ml}$ \\
\hline 0.1 Tris & $6.05 \mathrm{~g}$ & $50 \mathrm{mM}$ EDTA, $\mathrm{pH} 8.0$ & $50 \mathrm{ml}$ \\
\hline $\begin{array}{l}5 \mathrm{mM} \text { EDTA-Na2 } \\
\text { salt }\end{array}$ & $0.95 \mathrm{~g}$ & $2 \mathrm{M} \mathrm{NaCl}$ & $200 \mathrm{ml}$ \\
\hline ddH $_{2} 0$ & Up to $0.5 \mathrm{~L}$ & $\begin{array}{l}2 \% \mathrm{CTAB} \text { (diluted separately } \\
\text { in water then added to buffer } \\
\# 2)\end{array}$ & $10 \mathrm{~g}$ \\
\hline pH (with $\mathrm{HCl})$ & 8.25 & dd $\mathrm{H}_{2} 0$ & Up to $0.5 \mathrm{~L}$ \\
\hline
\end{tabular}

\section{Primers and PCR Conditions}

The primers used for the verification of POK presence are: 


\begin{tabular}{|l|l|}
\hline \multicolumn{2}{|c|}{ Table 3: PCR primers } \\
\hline AtTP1prom-B4/Br1 AN (TP ${ }_{1}$ antisense) & $\begin{array}{l}\text { GGGGACAACTTTGTATAGAAAAGTT } \\
\text { GTACGTAGCCCAACACTCGAATC }\end{array}$ \\
\hline AtTP1prom-B4/Br1 SE (TP ${ }_{1}$ sense) & GGGGACTGCTTTTTTGTACAAACTTG \\
& CGGTCGCTTATTGATTGTTTTCTCTCT \\
CC \\
\hline tdTOM Asc1 AN (tdTOM antisense) & $\begin{array}{l}\text { TGGCGCGCCCTTGTACAGCTCGTCCA } \\
\text { TGCCGT }\end{array}$ \\
\hline
\end{tabular}

The PCR conditions for both PCRs were: the denaturing condition was 94 degrees Celsius for 20 seconds, annealing was 56 degrees Celsius for 30 seconds, and the elongation conditions were 72 degrees Celsius for 1.5 minutes. 


\section{REFERENCES}

Ambrose, C., J.F. Allard, E.N. CYTRYNBAum, AND G.O. WASTENEYS. 2011. A CLASPmodulated cell edge barrier mechanism drives cell-wide cortical microtubule organization in Arabidopsis. Nature communications 2: 430.

ATKINSON, S., A. KIRIK, AND V. KIRIK. 2014. Microtubule array reorientation in response to hormones does not involve changes in microtubule nucleation modes at the periclinal cell surface. Journal of Experimental Botanyeru325.

BADESCU, GO, AND RM NAPIER. 2006. Receptors for auxin: will it all end in TIRs? Available at:

http://www.sciencedirect.com/science/article/pii/S1360138506000598.

BeChtold, N, J ELLIS, AND G PELLETIER. 1993. In planta Agrobacterium mediated gene transfer by infiltration of adult Arabidopsis thaliana plants. Available at: http://cat.inist.fr/?aModele=afficheN\&cpsidt=3816523.

Burk, D., B. LiU, R. Zhong, W. Morrison, AND Z.-H. YE. 2001. A Katanin-like Protein Regulates Normal Cell Wall gBiosynthesis and Cell Elongation. The Plant Cell Online 13: 807-827.

Camilleri, C., J. Azimzadeh, M. Pastuglia, C. Bellini, O. Grandjean, And D. BouCHEZ. 2002. The Arabidopsis TONNEAU2 Gene Encodes a Putative Novel Protein Phosphatase 2A Regulatory Subunit Essential for the Control of the Cortical Cytoskeleton. The Plant Cell Online 14: 833845.

CaO, L., L. Wang, M. Zheng, H. CaO, L. Ding, X. Zhang, And Y. Fu. 2013. Arabidopsis AUGMIN subunit8 is a microtubule plus-end binding protein that promotes microtubule reorientation in hypocotyls. The Plant cell 25: 2187-201.

Chan, J., M. Eder, E. Crowell, J. HAMpson, G. CAlder, And C. Lloyd. 2011. Microtubules and CESA tracks at the inner epidermal wall align independently of those on the outer wall of light-grown Arabidopsis hypocotyls. Journal of cell science 124: 1088-94. 
Chan, J., A. Sambade, G. CAlder, And C. Lloyd. 2009. Arabidopsis Cortical Microtubules Are Initiated along, as Well as Branching from, Existing Microtubules. The Plant Cell Online 21: 2298-2306.

Chen, JG, S Shimomura, F Sitbon, And G SANDBERg. 2001. The role of auxinbinding protein 1 in the expansion of tobacco leaf cells. Available at: http://onlinelibrary.wiley.com/doi/10.1046/j.1365-313x.2001.01152.x/full.

EHRHARDT, D., AND S. SHAW. 2006. MICROTUBULE DYNAMICS AND ORGANIZATION IN THE PLANT CORTICAL ARRAY. Annual Review of Plant Biology 57: 859875.

FISHEL, E., AND R. DIXIT. 2013. Role of nucleation in cortical microtubule array organization: variations on a theme. The Plant Journal 75: 270-7.

FRANK, MJ, AND LG SMITH. 2002. A small, novel protein highly conserved in plants and animals promotes the polarized growth and division of maize leaf epidermal cells. Available at:

http://www.sciencedirect.com/science/article/pii/S0960982202008199.

Fu, Y., Y. GU, Z. Zheng, G. WASTEneys, AND Z. YANG. 2005. Arabidopsis Interdigitating Cell Growth Requires Two Antagonistic Pathways with Opposing Action on Cell Morphogenesis. Cell 120: .

FU, Y., H. LI, AND Z. YANG. 2002. The ROP2 GTPase Controls the Formation of Cortical Fine F-Actin and the Early Phase of Directional Cell Expansion during Arabidopsis Organogenesis. The Plant Cell Online 14: 777-794.

FU, Y., T. XU, L. ZHU, M. WEN, AND Z. YANG. 2009. A ROP GTPase signaling pathway controls cortical microtubule ordering and cell expansion in Arabidopsis. Current biology : CB 19: 1827-32.

Gutierrez, R., J.J. LindeboOM, A.R. PAREDEZ, A.C. EMOns, AND D.W. EhrhardT. 2009. Arabidopsis cortical microtubules position cellulose synthase delivery to the plasma membrane and interact with cellulose synthase trafficking compartments. Nature Cell Biology 11: 797-806. Available at: http://www.nature.com/ncb/journal/v11/n7/abs/ncb1886.html.

Jones, AM, KH IM, MA SAVKa, MJ Wu, AND NG DEWITT. 1998. Auxin-dependent cell expansion mediated by overexpressed auxin-binding protein 1. Available at: http://www.sciencemag.org/content/282/5391/1114.short.

Jones, A. 1994. Auxin-Binding Proteins. Annual Review of Plant Physiology and Plant Molecular Biology 45: 393420. 
KIGEL, J, AND DJ CosGrovE. 1991. Photoinhibition of Stem Elongation by Blue and Red Light Effects on Hydraulic and Cell Wall Properties. Available at: http://www.plantphysiol.org/content/95/4/1049.short.

KIRIK, A., D. EHRHARDT, AND V. KIRIK. 2012. TONNEAU2/FASS regulates the geometry of microtubule nucleation and cortical array organization in interphase Arabidopsis cells. The Plant cell 24: 1158-70.

Lin, D., L. CAO, Z. Zhou, L. ZhU, D. Ehrhardt, Z. YANG, AND Y. Fu. 2013. Rho GTPase Signaling Activates Microtubule Severing to Promote Microtubule Ordering in Arabidopsis. Current Biology 23: .

LindeboOm, J., M. NaKamura, A. Hibbel, K. ShundyaK, R. Gutierrez, T. KetelaAr, A. EMONS, ET AL. 2013. A Mechanism for Reorientation of Cortical Microtubule Arrays Driven by Microtubule Severing. Science 342: 1245533.

LipKa, E., A. GAdeyne, D. StÖckle, S. Zimmermann, G. JAEGER, D. EhrhardT, V. KIRIK, ET AL. 2014. The Phragmoplast-Orienting Kinesin-12 Class Proteins Translate the Positional Information of the Preprophase Band to Establish the Cortical Division Zone in Arabidopsis thaliana. The Plant Cell Online 26: 26172632.

MurATA, T, S SONOBE, TI BASKIN, AND S HyOdO. 2005. Microtubule-dependent microtubule nucleation based on recruitment of $\gamma$-tubulin in higher plants. Available at: http://www.nature.com/ncb/journal/v7/n10/abs/ncb1306.html.

Müller, S., S. HAN, AND L. SMITH. 2006. Two Kinesins Are Involved in the Spatial Control of Cytokinesis in Arabidopsis thaliana. Current Biology 16: 888894.

NAKAMURA, M, AND T HASHIMOTO. 2009. A mutation in the Arabidopsis $\gamma$-tubulincontaining complex causes helical growth and abnormal microtubule branching. Available at: http://jcs.biologists.org/content/122/13/2208.short.

PARAdeZ, A, A Wright, AND DW EhrhardT. 2006. Microtubule cortical array organization and plant cell morphogenesis. Available at: http://www.sciencedirect.com/science/article/pii/S1369526606001464.

Sambade, A., A. Pratap, H. Buschmann, R. Morris, and C. Lloyd. 2012. The influence of light on microtubule dynamics and alignment in the Arabidopsis hypocotyl. The Plant cell 24: 192-201.

Shani, E, R WEINSTAIN, AND Y ZHANG. 2013. Gibberellins accumulate in the elongating endodermal cells of Arabidopsis root. Available at: http://www.pnas.org/content/110/12/4834.short. 
SHAW, SL, R KAMYAR, AND DW EHRHARDT. 2003. Sustained microtubule treadmilling in Arabidopsis cortical arrays. Available at: http://www.sciencemag.org/content/300/5626/1715.short.

SHIBAOKA, H. 1974. Involvement of wall microtubules in gibberllin promotion and kinetin inhibition of stem elongation. Available at: http://pcp.oxfordjournals.org/content/15/2/255.short.

TORRES-RUIZ, R.A., AND G. JÜRGENS. 1994. Mutations in the FASS gene uncouple pattern formation and morphogenesis in Arabidopsis development. Development (Cambridge, England) 120: 2967-78.

UEDA, K, T MATSUYAMA, AND T HASHIMOTO. 1999. Visualization of microtubules in living cells of transgenic Arabidopsis thaliana. Available at: http://link.springer.com/article/10.1007/BF01279267.

Vineyard, L., A. Elliott, S. Dhingra, J. LuCAS, And S. Shaw. 2013. Progressive transverse microtubule array organization in hormone-induced Arabidopsis hypocotyl cells. The Plant cell 25: 662-76.

WASTENEYS, G.O., AND M.E. GALWAY. 2003. Remodeling the cytoskeleton for growth and form: an overview with some new views. Annual Review of Plant Biology 54: 691-722. Available at: http://www.annualreviews.org/doi/abs/10.1146/annurev.arplant.54.031902.1348 18.

Wightman, R., G. CHOMicki, M. KUMAR, P. CARR, AND S.R. TURNER. 2013. SPIRAL2 determines plant microtubule organization by modulating microtubule severing. Current biology : CB 23: 1902-7.

WightMAN, R., AND S.R. TURNER. 2007. Severing at sites of microtubule crossover contributes to microtubule alignment in cortical arrays. The Plant journal : for cell and molecular biology 52: 742-51.

WU, G., Y. GU, S. LI, AND Z. YANG. 2001. A genome-wide analysis of Arabidopsis Ropinteractive CRIB motif-containing proteins that act as Rop GTPase targets. The Plant cell 13: 2841-56.

Xu, T., M. Wen, S. Nagawa, Y. Fu, J.-G. Chen, M.-J. Wu, C. Perrot-Rechenmann, et AL. 2010. Cell surface- and rho GTPase-based auxin signaling controls cellular interdigitation in Arabidopsis. Cell 143: 99-110.

YuAN, M., R.M. WARN, P.J. SHAW, AND C.W. LlOYD. 1995. Dynamic microtubules under the radial and outer tangential walls of microinjected pea epidermal cells observed by computer reconstruction. The Plant journal : for cell and molecular biology 7: 17-23. 